\title{
Picasso on Staff: Employee Classification, Copyrights, and the Creative Process
}

\author{
Sarah A. Howes
}

Follow this and additional works at: https://open.mitchellhamline.edu/cybaris

Part of the Intellectual Property Law Commons

\section{Recommended Citation}

Howes, Sarah A. (2016) "Picasso on Staff: Employee Classification, Copyrights, and the Creative Process," Cybaris $\AA^{\circ}$ : Vol. 7 : Iss. 1 , Article 5.

Available at: https://open.mitchellhamline.edu/cybaris/vol7/iss $1 / 5$

This Article is brought to you for free and open access by the Law Reviews and Journals at Mitchell Hamline Open Access. It has been accepted for inclusion in Cybaris ${ }^{\circledR}$ by an authorized administrator of Mitchell Hamline Open Access. For more information, please contact sean.felhofer@mitchellhamline.edu. (c) Mitchell Hamline School of Law

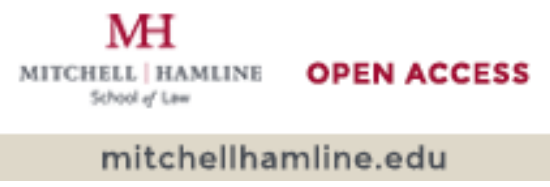




\title{
PICASSO ON STAFF \\ EMPLOYEE CLASSIFICATION, COPYRIGHTS, AND THE CREATIVE PROCESS
}

\author{
SARAH A. HOWES ${ }^{1}$
}

I. INTRODUCTION 162

A. ART AS A BUSINESS OR AS A JOB …………………............. 165

B. MinNESOTA AND HollywOOd ARTS ECOSYSTEMS ........... 166

C. Freelance ARtists ANd How LitTle We KnOW ............. 168

II. CREATIVITY IS ON THE RISE 170

III. EMPLOYEE CLASSIFICATION 174

A. OVERVIEW OF EMPLOYEE ClaSSIFICATION .......................... 174

B. MisclassificATION IN THE ARTS: BALlerinAS \& OPERA

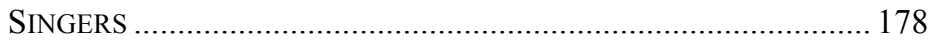

C. Uber Case Sparks New Policy Debates About How We

CLASSIFY EMPLOYEES …........................................................ 180

IV. INTELLECTUAL PROPERTY CONCERNS 182

A. CONTRACTORS OWN COPYRIGHTS ................................... 182

1. Post-1978 Employer-Employee Test ...................... 184

2. Pre-1978 Employer-Employee Test ......................... 186

B. CONTRACTORS CAN TERMINATE....................................... 189

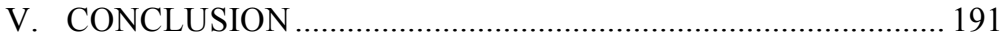

\section{INTRODUCTION}

Pablo Picasso, the Spanish painter who was responsible for 20,000 pieces of art $^{2}$ had a learning style that many of us creatives can

\footnotetext{
${ }^{1}$ Sarah A. Howes, J.D. is a non-union stage actor, and Dramatists Guild of America Associate Member. She is currently a Legal Fellow at the Copyright Alliance in Washington, D.C., and sits on the PAHRTS (Performing Arts Human Resources Toolkit Series) advisory committee with the Minnesota Theater Alliance. Prior to her fellowship, she was the Legal Programs Manager for the Minnesota Lawyers for the Arts program at Springboard for the Arts in St. Paul, Minn. The views expressed are not attributable to the Copyright Alliance, or any of her current or former employers, and was written in the author's personal capacity. The author would like to thank Molly Littman, Editor in Chief, for her intelligent feedback and warm encouragement.

2 Pablo Picasso (1881-1973), Metropolitan Museum of ART, http://www.metmuseum.org/toah/hd/pica/hd_pica.htm ("Even in his eighties and nineties, Picasso produced an enormous number of works and reaped the financial benefits of his success, amassing a personal fortune and a superb collection of his own art, as well as work by other artists.").
} 
relate to. Based on historical accounts, he surely would have been a complicated employee to manage. He regularly abandoned his art school homework for more time to sketch what he wanted. ${ }^{3}$ Classical techniques bored him, and he was resentful of teachers who attempted to conform him. ${ }^{4}$ It was not until he left art school in Madrid that he actually found a learning environment suitable for his personality. ${ }^{5} \mathrm{In}$ 1899, he joined a "cluster" of artists in Barcelona at the famous El Quatre Gats café, which "in lieu of an art school environment ... provided Picasso with an arguably more productive education."

Creative economist John Howkins uses the term "cluster" broadly to describe collaborative environments where he believes "creativity and innovation are sharpened."7 Today, many products are developed by groups of Picassos, calling on diverse learners and specialties to exchange ideas and provide invaluable criticism. ${ }^{8}$ Filmmaker Tiffany Shlain, a "Picasso" herself, believes the creative process involves finding a team of collaborators who are willing to build from one of her many "hunches," and to give her constructive feedback that acknowledges both the good and the bad of her work. ${ }^{9}$ This Emmy-nominated filmmaker and Webby Awards founder is perhaps thought of as a solo artist, because she narrates all of her films; but in actuality, she operates in a team environment. Her films are made both through The Moxie Institute and Let it Ripple, her nonprofit film studio her film studio, that employs - not contracts - a creative team of four core team members. ${ }^{10}$ She also provides her small creative workforce health and dental benefits. ${ }^{11}$

${ }^{3}$ Pablo Picasso: Painter (1881-1973), BIO., http://www.biography.com/people/pablopicasso-9440021?page=1\#early-life-and-education (last visited Oct. 18, 2015).

${ }^{4} I d$.

${ }^{5} \mathrm{Id}$.

${ }^{6}$ WiLLIAM SCHMEISER, AN INTRODUCTION TO PICASSO loc. 346 (2014) (ebook).

${ }^{7}$ John Howkins, The Creative Economy: How People MaKe Money From Ideas 61 (2d ed. 2013).

${ }^{8}$ See Knoll Workplace Research, Creating Collaborative Spaces that Work: A Performance-based Approach to Successful Planning, KNOLL, 2-3 (2013), https://www.knoll.com/media/315/283/CollaborativeWorkplace_wp.pdf (noting that companies invest in collaborative workspaces because it encourages innovation, speeds up decision-making, and to cross expertise).

${ }^{9}$ Tiffany Shlain, The Creative Process in 10 Acts Farnam Street (Nov. 4, 2015), https://www.farnamstreetblog.com/2015/11/tiffany-shlain-creative-process/.

${ }^{10}$ Email Interview with Tiffany Schlain, Filmmaker, The Moxie Institute, November 29, 2015 ("I have a core team of staff people (employees) and then I always work with other people animators, composers, writers, etc that work for themselves and we are partnering on a project"); The Team, Moxie Institute (last visited December 30, 2015), 
I love having people that I have worked creatively [with] for years. My producer and co-writer Sawyer Steele and I have made films together for nearly 10 years. Nothing can replace that history and institutional knowledge. Also, at this point, while there are many sprints to finish films, this is more of a long run, so I want everyone to feel they are taken care of with vacation and health care. ${ }^{12}$

Fewer and fewer employers share Shlain's labor philosophies: by 2020 a troubling $40 \%$ of the U.S. workforce is predicted to be contractors $^{13}$ (or other forms of contingent-status workers). ${ }^{14}$ Employee-status positions often provide workers livable wages, security, health benefits, ${ }^{15}$ and access to many state and federal

http://www.moxieinstitute.org/team; Full-Time Event Producer / Director, Let it Ripple, http://www.letitripple.org/full-

time event producer director?utm campaign=bat winter $2015 \& u$ tm medium=email\& utm_source=moxieinstitute (last visited December 30, 2015) (advertising a sixth fulltime position with health benefits).

11 Full-time Event Producer/Director (job posting), LET IT RIPPLE, http://www.letitripple.org/full-

time_event_producer_director?utm_campaign=bat_winter_2015\&utm_medium=email\& utm_source=moxieinstitute.

${ }^{12}$ Email interview with Tiffany Shlain, Filmmaker, The Moxie Institute (Jan. 20, 2016).

${ }^{13}$ There is little data out there to show the full impact on classification in the arts markets. When organizations invest in studies, it is typically to prove economic growth with respect to retail sales or the number of jobs without focus on the quality of such work. We do know that "American artists are highly entrepreneurial, they are 3.5 times more likely than the total U.S. workforce to be self-employed," which, again, selfemployment is not necessarily a bad thing for those who are well-compensated. Creative Minnesota, The Health and ImPaCt of THE NonProfit ARTS AND CUlTURE INDUSTRY IN THE STATE OF MINNESOTA 9 (2015), http://creativemn.org/wpcontent/uploads/2015/01/CreativeMN2015Book.pdf. See generally MinNEAPOLIS CREATIVE VITALITY INDEX (2014), http://www.ci.minneapolis.mn.us/www/groups/public/@citycoordinator/documents/webc ontent/wcms1p-135695.pdf.

${ }^{14}$ Intuit 2020 Report: Twenty Trends That Will Shape the Next Decade, INTUIT 21 (Oct. 2010) http://httpdownload.intuit.com/http.intuit/CMO/intuit/futureofsmallbusiness/intuit_2020_report.pdf

is ObamaCare Employer Mandate, OBAMACARE FACTS (last visited Dec. 30, 2015), http://obamacarefacts.com/obamacare-employer-mandate/ ("ObamaCare's "employer mandate' is a requirement that all business with 50 or more full-time equivalent employees provide health insurance to at least $95 \%$ of their full-time employees and dependents up to age 26 .'). 
employment laws that contractors miss out on, such as: unemployment insurance, minimum wage standards, family medical leave protections, workers' compensation, protection from employer sexual harassment, and the ability to collectively bargain under the National Labors Relations Act. ${ }^{16}$

\section{A. Art as a Business or as a Job}

To Picasso, creativity led to great artwork. But creativity is not, nor should it be, reserved for the visual arts. There is true market value in creativity and the creative persons who spin it. ${ }^{17}$ There are different theories on what creativity is: is it a method for solving problems ${ }^{18}$ a talent reserved for a select few, or rather a universal channel for how we use our intelligence? ${ }^{19}$ Personally, I find comfort in the belief that creativity is how we apply knowledge to new ideas. ${ }^{20}$ This non-legal definition honors the creative process by accounting for all manifestations, and is broad enough to suggest that every human possesses creative capacity. But surely not every human is capable of creating great products, and not every industry or community has perfected how to profit from art.

Pablo Picasso is an outlier: he made a large fortune $(\$ 50$ million net worth at his death) $)^{21}$ from his artwork. Few artists become millionaires from their craft, as Picasso did. Many artists simply seek livable wages. Springboard for the Arts, a leading economic development organization, teaches artists how to capitalize on their local audiences, and to manage their business affairs so they can make a "living and a life." 22 Laura Zabel, Springboard Executive Director, disagrees with the belief that artists are bad entrepreneurs:

\footnotetext{
${ }^{16}$ Appendix 1: Federal and Minnesota State Employee Classification Chart.

${ }^{17}$ See infra Part II.

${ }^{18}$ See generally Scott G. Isaksen, CPS: Linking Creativity and Problem Solving Creative Problem Solving Group, http://www.cpsb.com/research/articles/creativeproblem-solving/CPS-LinkingCandPS.html.

${ }^{19}$ See infra Part IV.

${ }^{20}$ W. Glenn Griffin \& Deborah Morrison, The Creative Process Illustrated: HOW BIG IDEAS ARE BORN 8 (2010).

${ }^{21}$ Christi Danner, Artists Who Got Rich Before They Died, Complex, Apr. 17, 2014, http://www.complex.com/style/2014/04/artists-who-got-rich-before-they-died/.

${ }^{22}$ Springboard for the Arts, http://springboardforthearts.org (last visited Dec. 30, 2015).
} 
I don't think artists are bad at being entrepreneurial. I think there are a lot of skills that artists have that lend themselves naturally to being entrepreneurial: artists already have a DIY ethic about their work, they're used to wearing a lot of hats and they understand a lot intuitively about engaging clients and audiences, about collaboration and iteration. But I also think the landscape for artists has changed a lot in the last decade. A lot of communities have seen decreased funding for arts and culture and the kind of structure that used to support artists-patronage structure or theater companies where they used to have a resident company and now hire everybody freelance, or the same thing for visual artists with galleries. So artists, more and more, are needing to be their own boss and manage all the details and run their careers like a business. A lot of training for artists hasn't caught up to that yet. ${ }^{23}$

Certainly some artists prefer being entrepreneurs, but others, as Zabel mentioned, only choose self-employment in response to the loss or lack of full-time work. ${ }^{24}$

\section{B. Minnesota and Hollywood Arts Ecosystems}

The number of employee-status positions is connected to overall economic viability of a community and the health of collaborative art forms.

Arts businesses and the creative people they employ stimulate innovation, strengthen America's competitiveness in the global

\footnotetext{
${ }^{23}$ Karsten Strauss, How Entrepreneurship Can Save the Starving Artist, FORBES, Dec. 18, 2015, http:/www.forbes.com/sites/forbestreptalks/2015/12/18/how-entrepreneurship-cansave-the-starving-artist/ (interviewing Laura Zabel, Executive Director of Springboard for the Arts).

${ }^{24}$ See generally Elaine L. Edgcomb \& Tamra Thetford, Microenterprise Development as Job Creation, THE ASPEN INSTITUTE, Feb. 1, 2013 , http://fieldus.org/Publications/JobCreation.pdf; Karsten Strauss, How Entrepreneurship Can Save the Starving Artist, FORBES, Dec. 18, 2015, http:/www.forbes.com/sites/forbestreptalks/2015/12/18/how-entrepreneurship-can-savethe-starving-artist/ (interviewing Laura Zabel, Executive Director of Springboard for the Arts).
} 
marketplace, and play an important role in building and sustaining economic vibrancy. ${ }^{25}$

In Minnesota, for example, the nonprofit arts and culture section has a substantial impact on the State: total economic impact is $\$ 1.2$ billion. ${ }^{26}$ What is particularly fascinating about this data is its relationship to employment. $1.5 \%$ of the entire Minnesota workforce is artists; whereas the national average sits at a mere $1.1 \% .{ }^{27}$ This figure is likely due to certain industries and professions supporting more fulltime employment (theater, museums, and most notably book publishing). However, in Minnesota, there are less fulltime positions for independent artists, writers, and performers than the national average. ${ }^{28}$

The U.S. film industry - a drastically different ecosystem than the one found in the Minnesota arts community - is the largest in the world, and supports 302,000 direct workers, paying $\$ 47$ billion in wages. ${ }^{29}$ Even more extraordinary is that while Hollywood is not perfect - with instances of questionable unpaid interns ${ }^{30}$ and $79 \%$ of freelancers experiencing nonpayment at least once in their careers ${ }^{31}$ its employees bring home salaries $43 \%$ higher than the national average. ${ }^{32}$ This could be due to the strong labor union system inside of

\footnotetext{
${ }^{25}$ For a general map of how job creation in the arts leads to a healthy society, see the following study: AMERICANS FOR THE ARTS, THE CREATIVE INDUSTRIES IN THE UNITED STATES (2015), http://www.americansforthearts.org/sites/default/files/pdf/2015/by_program/reports_and_ data/research_studies_and_publications/creative_industries/2015_United_States.pdf ("702771 Arts-Related Businesses Employ 2,909,382 people").

${ }^{26}$ Minnesota Citizens for the Arts, Minnesota Creative: The Impact AND HEALTH OF NONPROFit ARTS AND Culture SECTOR 3 (2015), http://www.culturaldata.org/wp-content/uploads/creative-minnesota-impact-healthnonprofit-arts-culture-sector.pdf.

${ }^{27}$ Id. at 9.

${ }^{28} \mathrm{Id}$.

29 Creating Jobs, Motion Picture Assoc. AM., Nov. 20, 2015, http://www.mpaa.org/creating-jobs/.

${ }^{30}$ E.g. Glatt v. Fox Searchlight Picture, Inc., 791 F. 3d 376 (2d Cir. 2015) (class action lawsuit brought by unpaid interns against the motion picture distribution company).

${ }^{31}$ Laura Murphy, Glitz, Glamour \& Unpaid Bills : The nonpayment problem in film and television, FREELANCERS UNION, Dec. 22, 2015, https://www.freelancersunion.org/blog/2015/12/22/glitz-glamour-unpaid-billsnonpayment-problem-film-and-television/.

${ }^{32}$ The Economic Contribution of the Motion Picture \& Television Industry to the United States, MOTION PICTURE ASSOC. AM., Sept. 2014, http://www.mpaa.org/wpcontent/uploads/2014/09/2014-MPAA-Industry-Economic-Contribution-Factsheet.pdf
} 
Hollywood. ${ }^{33}$ For example, SAG-AFTRA - the labor union that represents 160,000 actors and other media performers-requires, with exemption, that producers classify SAG members as employees. ${ }^{34}$ It is also in Hollywood that we have many full-time positions for writers, another artist traditionally thought of as a contractor. Hollywood has succeeded, arguably more than any other industry, in creating a professional class of artists. Artists who can both invest in their craft and pay their bills.

\section{C. $\quad$ Freelance Artists and How Little We Know}

This is what little we know about the U.S. artist workforce as it relates to this topic:

American artists are highly entrepreneurial; they are 3.5 times more likely than the total U.S. workforce to be self-employed.

American artists are generally more educated than other workers. Over half of all artists have received at least a bachelor's degree.

American artists are less likely than other workers to have full-year or full-time employment, which partly accounts for their annual median incomes being lower than those of workers with similar levels. ${ }^{35}$

I suspect that many employers do not need a staff painter, photographer, writer, or actor because any need might be sporadic or

\footnotetext{
${ }^{33}$ E.g., White House Summit on Worker Voice, October 7, 2015 (interview of President Barack Obama), available at https://www.whitehouse.gov/campaign/worker-voice ("I am big believer of ... collective bargaining and unions as a tool to empower workers ... unions made sure ... there were direct negotiations, and the workers were at the table ... provided muscle and lift to get [legislation] passed.").

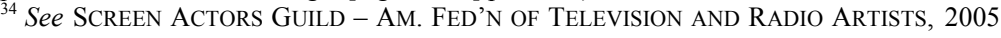
SAG BASIC AGREEMENT http://www.sagaftra.org/files/sag/2005TheatricalAgreement.pdf. One reason for this phenomenon is that labor laws only have jurisdiction over "employees." See 29 U.S.C. § 152(3) (2015). Union contracts thus require hiring parties to classify labor union members as employees, regardless of duration.

${ }^{35}$ Minnesota Citizens for THE ARTS, Minnesota CREATIVE: ThE IMPACT AND HEALTH OF NONPROFIT ARTS AND CUlTURE SECTOR 9 (2015) (citing National Endowment for the Arts, Artists and Arts Workers in the United States: Findings from the American Community Survey (2005-2009) and the Quarterly Census of Employment and Wages (2010)).
} 
limited. Other reasons why so many employers hire artists as freelancers might be small operating costs, or simply the incorrect view that creative labor is not labor under the law. There is no survey, at least not one that I can find, to say why it is that employers choose to classify artists as contractors, or even how many artists out there are employees, contractors, or misclassified. But, we do know that contractor-status is one explanation for why artists make such little money. ${ }^{36}$

There is no denying that hiring employees over contractors is more expensive. ${ }^{37}$ "At face value, building a workforce this way seems like a no-brainer for many startups, which save about $30 \%$ on the cost of labor by paying workers as independent contractors." 38

But what impact will this way of doing business have on finished products or services? Hiring an employee means you, the employer, have no restrictions in terms of collaboration, direction, or how you decide to power the creative process. ${ }^{39}$ There are limitations under the law to how you can manage and collaborate with a contractor that many managers would seemingly like to avoid. Furthermore, will the growing use of contractors to perform creative functions increase the administration of termination rights, effectively shortening companies' copyright interests to thirty-five years? We are seeing the courts respond by reminding companies of the legal consequences of misclassifying workers, ${ }^{40}$ but the underlying concern might not be legal at all, but rather one of leadership. With the expansion of gig-economy type companies growing in popularity, there seems to be less focus on the worker, but a belief that good products will come about regardless.

This essay will introduce additional considerations to determining a creative worker's classification. Much of the current discussions on this topic have either been from a business or employment law lens, disregarding the impact on copyright interests

${ }^{36} I$ d.

${ }^{37}$ Hyam Singer, Don't Be Fooled: Calculate the Real Cost of Employees and Consultants, TOPTAL DEVELOPERS, http://www.toptal.com/freelance/don-t-be-fooled-thereal-cost-of-employees-and-consultants (last visited Oct. 6, 2015) (According this this calculation, a contractor will cost less than an employee even when the contractor makes $\$ 70$ an hour and the employee makes $\$ 46$ an hour).

${ }^{38}$ Sarah Kessler, In A Backlash to the Gig Economy, Hiring Employees is Cool Again in Silicon Valley, FAST COMPANY (June 10, 2015, 6:06 AM), http://www.fastcompany.com/3047105/a-backlash-to-the-gig-economy-hiringemployees-to-do-work-is-cool-in-silicon-valley-again.

${ }^{39}$ See infra note 147 and accompanying text.

${ }^{40}$ See O’Connor v. Uber Techs., Inc., 82 F. Supp. 3d 1133 (N.D. Cal. 2015). 
and the creative process. ${ }^{41}$ The needs of a position ought to define the classification, not the 1099 discount. ${ }^{42}$ Under the existing legal framework, companies and creative workers can organize in a mutually beneficial way. My goal for this essay is to persuade companies to rethink how they approach employee classification and utilize the current law for such mutual benefit.

Part I provides a discussion of how our society is asking for more and more creative products and some of the challenges of managing creative workers. Part II gives an overview of how employees are legally classified, and provides some misclassification cases brought by Uber drivers and performing artists. Finally, part III analyzes how employee classification impacts intellectual property rights and plays into the application of the termination right.

\section{CREATIVITY IS ON THE RISE}

According to Americans for the Arts, ${ }^{43}$ "the value of the creative is on the rise" as blue-collar positions decline. ${ }^{44}$ That is, the need for creative positions is increasing in our entertainment-focused society. For example, the average U.S. adult will watch five hours and thirty-one minutes of video each day. ${ }^{45}$ Music consumption is growing as well, as paid streaming subscriptions made up thirty-three percent of total industry revenues from 2014 to 2015 , up from 26 percent in

${ }^{41}$ E.g., Julien M. Mundale, Note: Not Everything That Glitters is Gold, Misclassification of Employees: The Blurred Line Between Independent Contractors and Employees Under the Major Classification Tests, 20 SuffolK J. TRIAL \& APP. AdVOC. 253 (2015) (identifying the current legal climate as lacking the incentive for employers to properly classify their workers).

${ }^{42}$ For a quick primer on employment taxes, see ABA Section of Taxation, Employment Tax Primer for Small Businesses: I'm Ready to Hire My First Employee. What Should I Know About Taxes?, presented at the 2015 Joint Fall CLE Meeting (Sept. 18, 2015).

${ }^{43}$ Americans for the Arts serves, advances, and leads the network of organizations and individuals who cultivate, promote, sustain, and support the arts in America. Founded in 1960, Americans for the Arts is the nation's leading nonprofit organization for advancing the arts and arts education.

${ }^{44}$ Felipe Buitrago Restrepo, Arts \& the Workforce, AM. FOR ARTS, 75 (2015), http://www.americansforthearts.org/sites/default/files/Arts\%26America_Workforce.pdf.

${ }^{45}$ US Adults Spend 5.5 Hours with Video Content Each Day, EMARKETER, Apr. 16, 2015, http://www.emarketer.com/Article/US-Adults-Spend-55-Hours-with-Video-Content-

Each-Day/1012362. 
2013. ${ }^{46}$ More than ever, Americans are tuning in, logging in, or clicking through media produced by creative professionals.

"In 2013, the value added by the core copyright industries to U.S. GDP reached more than $\$ 1.1$ trillion dollars." ${ }^{47}$ This creative economy, as measured by the core copyright industries, supports 5.5 million jobs. ${ }^{48}$ These workers sometimes work in isolation, and other times in collaborative environments with thoughtful direction. ${ }^{49}$ And all of these companies have at least one Pablo Picasso on staff, often many more. ${ }^{50}$ These people possess impeccable judgment and skill when it comes to design, the senses, and communication. ${ }^{51}$

One such Picasso is comedy writer and performer Tina Fey. After leaving college with a degree in drama, she went on to train at Second City, the school of improvisation in Chicago. ${ }^{52}$ While there, she learned to embrace a more collaborative creative process than her traditional Stanislavski acting training provided. ${ }^{53}$ Improvisational acting or sketch comedy writing requires equal part talent, equal part

${ }^{46}$ Joshua P. Friedlander, News and Notes on 2015 RIAA Music Industry Shipment and Revenue Statistics, RIAA, https:/www.riaa.com/wpcontent/uploads/2015/09/2015_RIAAMidYear_ShipmentData.pdf (last visited Jan. 9, 2016).

${ }^{47}$ Stephen E. Siwek, Copyright Industries in the U.S. Economy, INT'L INTELL. ProP. AllianCE, 2 (2014), http://www.iipa.com/pdf/2014CpyrtRptFull.PDF ("The "core" copyright industries are those industries whose primary purpose is to create, produce, distribute or exhibit copyright materials.").

${ }^{48}$ Stephen E. Siwek, Copyright Industries in the U.S. Economy, INT'L INTELL. Prop. AlLIANCE, 2 (2014), http://www.iipa.com/pdf/2014CpyrtRptFull.PDF. These numbers are based on the core copyright industries - those "whose primary purpose is to create, produce, distribute, or exhibit copyrighted material." I'd wish to account for a broader net of workers who engage in the creative process - not all creative products are protected by U.S. copyright law-but that data is not available.

${ }^{49}$ These skills are what many believe can make artists a most-valuable employee. See, e.g., Lisa Phillips, The Top 10 Skills Children Learn From the Arts, AM. FOR ARTS, Nov. 26, 2012, http://blog.americansforthearts.org/2012/11/26/the-top-10-skills-children-learnfrom-the-arts.

${ }^{50}$ Artists bring something valuable to the workforce, which is why companies like Another Limited Rebellion attempt to expand an artist skill set to other types of workers. Leah Lamb, Why You Should Hire an Artist as Your Next Business Consultant, FAST COMPANY (Sept. 18, 2015, 5:12 AM), http://www.fastcompany.com/3051224/hit-theground-running/why-you-should-hire-an-artist-as-your-next-business-consultant. ${ }_{51} I d$.

52 Tina Fey: “Bossypants," Google, Apr. 21, 2011, https://www.youtube.com/watch?v=M8Mkufm3ncc.

${ }^{53}$ Id . 
process, and equal part teamwork. ${ }^{54}$ She brought this training to the 30 Rock writing room, which is what arguably made the show's dialogue so brilliant. Kay Cannon, 30 Rock staff writer and Pitch Perfect screenwriter, remembers:

The first eight weeks [of writing for 30 Rock], everything was so new, and in preproduction you are sitting in a room full of people and you are just talking, and talking about your life, and coming up with ideas and pitching ideas and it's much more casual and laidback. And because I was new to this, I was like ' $\mathrm{Oh}$, is this what this is? $\mathrm{Cuz}$ [sic] this is easy. I can do this all day!' and then of course you get into the writing of it and you're like ' $\mathrm{Ok}$, this is hard." . . . Every day you've gotta bring it. ${ }^{55}$

One can assume, that the staff writer position gave her both the capacity to participate in a team writing environment, and the time for those slower, incubation periods that are key to the creative process. $^{56}$

Creativity's market value is not lost on executives. After research connected daydreaming to better ideas, many tech companies adopted "laziness" policies. ${ }^{57}$ Google, for example, lets workers dedicate some of their workday to goofing off. ${ }^{58}$ Daydreaming lets

${ }^{54}$ See generally KeLly LEONARD \& TOM YORTON, YeS, AND: How IMPROVISATION REVERSES "NO, BUT" THINKING AND IMPROVES CREATIVITY AND COLLABORATIONLESSONS FROM THE SECOND CITY (Harper Business 2015).

${ }^{55}$ Rachel Mason, Inside the Writer's Room: Behind the Scenes at 30 Rock with Writer/Producer Kay Cannon, SPLITSIDER, Oct. 14, 2010, http://splitsider.com/2010/10/inside-the-30-rock-writers-room-with-writerproducer-kaycannon/. Cannon, a Picasso and Writers Guildof America Award Winner, was an employee of NBC Universal. Id.

${ }^{56}$ In The Art of Thought, political scientist Graham Wallas broke the creative process into four stages: 1) preparation, 2) incubation, 3) illumination, and 4) verification. W. GLENN GrifFin \& DEBORAH MORRISON, THE CReAtive Process Illustrated: How ADVERTISING'S BIG IDEAS ARE BORN 6-7 (2010) (citing GRAHAM WALLAS, THE ART OF THOUGHT (Harcourt Brace 1926)).

57 Jonan Lehrer, The Virtues of Daydreaming, NEW YORKER, June 5, 2012 , http://www.newyorker.com/tech/frontal-cortex/the-virtues-of-daydreaming.

${ }^{58}$ See Jillian D'Onfro, The Truth About Google's Famous '20\% Time' Policy, Bus. INSIDER, Apr. 17, 2015, http://www.businessinsider.com/google-20-percent-time-policy2015-4. While the Google $20 \%$ policy is now said to be dead, some of its workers still claim to take advantage of it. $I d$. 
workers stimulate the senses, "think uncensored thoughts," make novel connections, and "tap into the most complex regions of [their] brain." 59 In Creativity, Inc., Pixar President Edwin Catmull shares an anecdote of how he threw away a table and its place cards when it became apparent that only executives were speaking up at meetings. ${ }^{60}$ When it comes to something as creative as making animated films, Catmull feels everyone needs to throw ideas into the hat. ${ }^{61}$ In his book, Catmull communicates his distaste for hierarchical work environments as being unsuitable for good storytelling. ${ }^{62}$ As Catmull details, he worked to design an environment conducive with the creative process. ${ }^{63}$

Creative geniuses are rare, and creativity is tricky to manage:

Managing creative employees can be challenging: It's a constant balancing act. On the one hand, you need to maintain an environment that encourages exploration, experimentation, and risk-taking. On the other hand, you need to push people forward to produce work on time and on budget that meets the needs of the business. ${ }^{64}$

Companies in the business of producing creative products need to prioritize the establishment of workplaces that are conducive to the creative process. Many Picasso-like thinkers contribute to our rich creative economy, and many of these thinkers benefit from the financial stability and collaborative environments afforded to them by employeeclassified positions.

Inspiring creativity in teams is no easy feat; it requires discipline, training, and company policies flexible enough to adapt to any creative environment or worker. ${ }^{65}$ As such, companies should

${ }^{59}$ Amy Fries, Sparking Creativity in the Workplace: Work and Daydreaming Really Do Go Together . . . Honest!, PSYCHOLOGY TODAY, Feb. 9, 2010, https://www.psychologytoday.com/blog/the-power-daydreaming/201002/sparkingcreativity-in-the-workplace.

${ }^{60}$ Ed CATMUll, CREATIVITY, INC. loc. 160-67 (2014).

${ }^{61} I d$. at loc. 166.

${ }^{62}$ See id at loc. 144

${ }^{63} \mathrm{Id}$.

${ }^{64}$ Nelson Rodriguez, 5 Keys to Successfully Manage Creative Employees, ENTREPRENEUR, Jan. 28, 2015, http://www.entrepreneur.com/article/242229.

${ }^{65}$ Richard Florida \& Jim Goodnight, Managing For Creativity, HARV. BUS. REV., JulyAug. 2005, https://hbr.org/2005/07/managing-for-creativity ("Though all people chafe under what they see as bureaucratic obstructionism, creative people actively hate it, 
know that under employment laws, labeling someone a proper contractor actually takes the company out of the creative process. ${ }^{66}$ And for most creative works out there, it also grants the creator the right to take the copyright back decades later. ${ }^{67}$

III. Employee Classification

\section{A. Overview of Employee Classification}

In response to a growing number of misclassification complaints across the country, ${ }^{68}$ the U.S. Department of Labor (DOL) recently released an Administrator's Interpretation to provide workers clarity on what makes a worker an employee under the Fair Labor Standards Act (FLSA). ${ }^{69}$ Clarity is difficult when employee classification is tested differently across state and federal laws. Each area of law maintains its own independent body of case law to guide it. $^{70}$

In Chaves v. King Arthur's Lounge an exotic dancer in Massachusetts was ruled to be an employee of the establishment because she performed her service in the lounge, the service was not customary in independently established business of the same nature,

viewing it not just as an impediment but as the enemy of good work. Do what you can to keep them intellectually engaged and clear petty obstacles out of their way, and they'll shine for you.").

${ }^{66}$ See infra Part IX.

${ }^{67}$ See infra Part X.

${ }^{68}$ Some predict that the government is growing more concerned with employee classification because of the 2008 recession's effect on unemployment insurance and the passage of the Affordable Care Act. Once reclassified, employers owe back pay, fines, and damages. Jeff Saviano \& Debera Salam, Why are Tax Audits Increasingly Focused on Incorrect Classification of Workers as Independent Contractors?, J. OF MULTISTATE TAX'N \& INCENTIVES, July 2015, at 32, 33.

${ }^{69}$ DAVID Weil, Wage \& Hour DiV., U.S. DeP'T OF LABOR, ADMINISTRATOR'S INTERPRETATION No. 2015-1 at 1, July 15, 2015, http://www.dol.gov/whd/workers/Misclassification/AI-2015_1.pdf.

${ }^{70}$ See Robert Sprague, Worker (Mis)Classification in the Sharing Economy: Square Pegs Trying to Fit in Round Holes, 31 ABA J. LABOR \& EMPLOYMENT (forthcoming 2015), http://works.bepress.com/cgi/viewcontent.cgi?article=1054\&context=robert_sprague;

Jack E. Karns, Current Federal and State Conflicts in the Independent Contractor Versus Employee Classification Controversy, 22 CAMPBELL L. REV. 105 (1999). See e.g., Gryga v. Ganzman, 991 F. Supp. 105, 109 (E.D.N.Y. 1998) ("Since the cases cited [, e.g., Cmty. for Creative Non-Violence v. Reid, 490 U.S. 730 (1989),] by defendant address a somewhat different issue-whether an individual is an 'employee' or an 'independent contractor' within the meaning of various federal statutes - they are not dispositive of the present motion."). 
and the lounge asserted direct control over her. In other states, if the same facts applied, the outcome would have differed, it may have also differed if the dancer's classification as made under the tax statutes or under the Fair Labor Standards Act. ${ }^{71}$

The common law agency test is the historical underpinning for employee classification analysis. It is applied in actions under the National Labor Relations Act, ${ }^{72}$ in many state employment laws, ${ }^{73}$ and —relevant to this discussion— copyright laws. ${ }^{74}$ Factors include:

1. The hiring party's right to control the manner and means by which the product is accomplished;

2. The skill required;

3. The source of the instrumentalities and tools;

4. The location of the work;

5. The duration of the relationship between the parties;

6. Whether the hiring party has the right to assign additional projects to the hired party;

7. The extent of the hired party's discretion over when and how long to work;

8. The method of payment;

9. The hired party's role in hiring and paying assistants;

10. Whether the work is part of the regular business of the hiring party;

11. Whether the hiring party is in business;

12. The provision of employee benefits; and

13. The tax treatment of the hired party. ${ }^{75}$

\footnotetext{
${ }^{71}$ Julien M. Mundele, Note, Not Everything that Glitters is Gold, Misclassification of Employees: The Blurred Line Between Independent Contractors and Employees Under the Major Classification Tests, 20 SuffolK J. TRIAL \& APP. Advoc. 253, 254 (2015) (citing Chaves v. King Arthur's Lounge, No. 07-2505, 2009 Mass. Super. LEXIS 298 (Mass. Super. Ct. July 30, 2009)) (citations omitted).

${ }^{72}$ E.g., Lancaster Symphony Orchestra and the Greater Lancaster Fed'n of Musicians, 357 N.L.R.B. No. 152, at *4 (2011).

Classification Tests, WORKERSCLASSIFICATION.COM, http://www.workerclassification.com/Classification-Tests (last visited Oct. 14, 2015).

${ }^{74}$ See Cmty. for Creative Non-Violence v. Reid, 490 U.S. 730, 751-52 (1989).

${ }^{75} \mathrm{Id}$. (citing Restatement (SECOND) OF AGENCY § 220 (1958)); see also Charles J. Muhl, What is an employee? The answer depends on the Federal law, MONTHLY LAB. REV., Jan. 2002, at 3, 7-8, http://www.bls.gov/opub/mlr/2002/01/art1 full.pdf.
} 
The FLSA - the federal law that sets minimum wage and overtime conditions-defines "employee" under the "economic realities" test. ${ }^{76}$ This test, also applied to Title VII of the Civil Rights Act, ${ }^{77}$ inquires as to whether "[a] worker is economically dependent upon the alleged employer or is instead in business for himself." Factors include:

1. The extent to which the work performed is an integral ${ }^{79}$ part of the employer's business;

2. The worker's opportunity for profit or loss depending on his or her managerial skills;

3. The extent of the relative investments ${ }^{80}$ of the employer and the worker;

4. Whether the work performed requires special skills and initiative ${ }^{81}$;

5. The permanency ${ }^{82}$ of the relationship; and

6. The degree of control exercised or retained by the employer. ${ }^{83}$

${ }^{76}$ Weil, supra note 69 , at 2.

${ }^{77} 42$ U.S.C. § 2000e, et seq. (2012). See Susan N. Houseman, 9.1 Who Is an Employee? Determining Independent Contractor Status, in U.S. DEP'T OF LABOR, A REPORT ON TEMPORARY Help, ON-CALl, DiRECT-HiRE TEMPORARY, LEASED, CONTRACT COMPANY, AND INDEPENDENT CONTRACTOR EMPLOYMENT IN THE UNITED STATES (1999),

http://www.dol.gov/dol/aboutdol/history/herman/reports/futurework/conference/staffing/ 9.1 contractors.htm (stating that the economic realities test "is often applied by courts in determining independent contractor status ...").

${ }^{78}$ Hopkins v. Cornerstone Am., 545 F.3d 338, 343 (5th Cir. 2008): see generally Nancy E. Dowd, The Test of Employee Status: Economic Realities and Title VII, 26 WM. \& MARY L. REV. 75 (1984) (detailing the economic realities test and arguing that the test thwarts the purpose of the law by being too narrow).

${ }^{79}$ Weil, supra note 69, at 7 ("For a construction company that frames residential homes, carpenters are integral to the employer's business because the company is in business to frame homes, and carpentry is an integral part of providing that service.").

${ }^{80} \mathrm{Id}$. at 9 ("The worker's investment must be significant in nature and magnitude relative to the employer's investment in its overall business to indicate that the worker is an independent businessperson.").

${ }^{81} I d$. at 10 ("A worker's business skills, judgment, and initiative, not his or her technical skill, will aid in determining whether the worker is economically independent.").

${ }^{82} \mathrm{Id}$. at 12 ("The key is whether the lack of permanence or indefiniteness is due to 'operational characteristics intrinsic to the industry' (for example, employers who hire part-time workers or use staffing agencies) or the worker's 'own business initiative.') (citing Brock v. Superior Care, 840 F.2d 1054,1060 (2d Cir. 1988)). 
While no one factor is determinative, the FLSA strives to "provide broad coverage for workers." 84 To the DOL, "the correct classification of workers as employees or independent contractors has critical implications for the legal protections that workers receive, particularly when misclassification occurs in industries employing low wage workers." 85

The Internal Revenue Service also has its own spin on the common law factors, grouping them into three categories: 1) behavioral control; ${ }^{86}$ 2) financial control $;{ }^{87}$ and 3 ) the relationship of the parties. ${ }^{88}$ Again, this body of regulations looks to know who had control or paid for expenses, and whether the work was a permanent and integral part of business operations. ${ }^{89}$

It seems employee classification differs among the various laws mostly in the underlying policies. As mentioned, the DOL has a policy to classify most workers as employees, whereas in copyright law-where employee classification deprives a worker of his or her copyright interests - the courts are hesitant to label a worker an employee. $^{90}$

It is estimated that between ten and twenty percent of employers are misclassifying their employees under these tests. ${ }^{91}$ One

${ }^{83} I d$. at 13. ("The worker's control over meaningful aspects of the work must be more than theoretical - the worker must actually exercise it.") (citing Dole v. Snell, 875 F.2d 802, 808 (10th Cir. 1989)).

${ }^{84} \mathrm{Id}$. at 4 .

${ }^{85} I d$. at 15.

${ }^{86}$ IRS TAX TOPICS 762, http://www.irs.gov/taxtopics/tc762.html; BEHAVIORAL CONTROLS, IRS, http://www.irs.gov/Businesses/Small-Businesses-\&-SelfEmployed/Behavioral-Control.

${ }^{87}$ IRS TAX TOPICS 762, http://www.irs.gov/taxtopics/tc762.html; FINANCIAL CONTROL, IRS, http://www.irs.gov/Businesses/Small-Businesses-\&-Self-Employed/FinancialControl.

88 IRS TAX TOPICS 762, http://www.irs.gov/taxtopics/tc762.html; TYPE OF RELATIONSHIP, IRS, http://www.irs.gov/Businesses/Small-Businesses-\&-SelfEmployed/Type-of-Relationship.

${ }^{89}$ See Employer's Supplemental Tax Guide, Publication 15-A, DeP'T OF THE TREASURY: INTERNAL REVENUE SERVICE, 8 (2015), https://www.irs.gov/pub/irs-pdf/p15a.pdf.

${ }^{90}$ Compare Weil, supra note 69, at 5, with Jessica Litman, Copyright, Compromise, and Legislative History, 72 CORNELL L. REV. 857, 890 (1987) ("[Pre-legislative dialogue of the 1976 Copyright Act] indicate that by using the term 'employee' the parties meant to limit works made for hire under this branch of the definition to works created by a salaried worker in a long-term position.").

${ }^{91}$ Francois Carre, (In)dependent Contractor Misclassification, ECON. POL'Y INST., June 8, 2015, http://www.epi.org/publication/independent-contractor-misclassification/. 
thing is certain, misclassification is a growing concern, even if its impacts are yet to be fully understood or felt.

\section{B. Misclassification in the Arts: Ballerinas \& Opera Singers}

In the Second Circuit, a prima ballerina ${ }^{92}$ was classified an employee under the Federal Tort Claims Act when she was injured at the Kennedy Center for Performing Arts. ${ }^{93}$ Per her employment contract, ${ }^{94}$ New York law applied: "the typical test of whether one is an independent contractor lies in the control exercised by the employer, and in who has the right to direct what will be done and when and how it will be done." 95 The ballerina met this test because she was hired to attend scheduled rehearsals and performances for "a specific part in a specific musical," wear particular clothes, and style her hair and makeup in a particular way. ${ }^{96}$

This opinion was consistent with New York law, where performers are typically found to be employees. ${ }^{97}$ All that is required is a showing that the employer has control "over such aspects of the workers' employment as the dates and times of performances and the work to be performed." 98

Interestingly, these same facts in other states would have resulted in an opposite result. In Minnesota, for example, a group of performers hired for short-term engagements by a small non-profit

\footnotetext{
${ }^{92}$ It should be stated that this ballerina was an Equity Actor. Her contract requires she be treated like an employee, but this relationship did not go into the court's analysis. Makarova v. U.S., 201 F.3d 110, 112 (2d Cir. 2000).

${ }^{93}$ In this unique scenario, the ballerina was disadvantaged in being an employee, as it made her ineligible to sue the government. $I d$. at 115 .

${ }_{94}^{94}$ The court continued to analyze the contract under D.C. law, and found the same result. It found her to be "in the service of" the Kennedy Center. Id.

${ }^{95} \mathrm{Id}$. at 114 .

${ }^{96} \mathrm{Id}$.

${ }^{97}$ Id.

${ }^{98}$ Id. at 115 (citing Challis v. Nat'l Producing Co., 275 A.D. 877, 88 N.Y.S.2d 731, 732

(3d Dept. 1949). See also Jack Hammer Assocs. v. Delmy Prods., 118 A.D.2d 441, 499, N.Y.S.2d 418, 419-20 (1st Dept. 1986).
} 
opera company ${ }^{99}$ were narrowly found to be contractors by the Minnesota Court of Appeals. ${ }^{100}$

In finding the performers to be contractors, ${ }^{101}$ the court disregarded any control inherent in the rehearsal process itself: "Artists who perform . . necessarily attend scheduled rehearsals and take directions from a director. If this type of control, without more, were enough to establish employee status, it is difficult to conceive of a circumstance in which an [artist] hired by a theater would not be an employee." 102 As opposed to New York law, the Minnesota Court of Appeals felt the performers were the ones in control: they prepared for roles in their own time, and were free to pursue other work. ${ }^{103}$ Although, it seems the court was mostly persuaded by the brevity of the performance schedules. ${ }^{104}$

Still, this was a close call for Minnesota - the decision itself cannot be cited in future cases. ${ }^{105}$ The court was clear, stating:

Our decision today is a narrow one. We merely hold, on the specific facts presented in this case ... our decision should not be construed to extend to all persons hired by operas, orchestras, or theaters. As we noted above, "[i]n employment-status cases, there is no general rule that covers all situations, and each case will depend in large part upon its own particular facts."

\footnotetext{
${ }^{99}$ The Skylark Opera Company is one of many small nonprofit performing arts organizations in Minnesota. ${ }^{99}$ The company hosts four performances each year, and employs only one permanent employee, its Artistic Director. Skylark Opera v. Dep't of Employment \& Econ. Dev., 2014 WL 4672360, at*1 (Minn. Ct. App. Sept. 22, 2014)

${ }^{100} \mathrm{Id}$. (analyzing why orchestra and technical staff were also contractors).

${ }^{101} \mathrm{Id}$. at *4 ("Traditionally, five factors are used to determine whether a worker is an employee or an independent contractor: '(1) The right to control the means and manner of performance; (2) the mode of payment; (3) the furnishing of material or tools; (4) the control of the premises where the work is done; and (5) the right of the employer to discharge."”).

${ }^{102}$ Skylark Opera, 2014 WL 4672360, at *4.

${ }^{103}$ Id. at $* 1-2$

${ }^{104} \mathrm{Id}$. at 5 .

${ }^{105} \mathrm{Id}$. ("Notice: This opinion is designated as unpublished and may not be cited except as provided by Minn. St. Sec. 480A.08(3).”).

${ }^{106} I d$. at *6 (citing St. Croix Sensory Inc. v. Dep't of Emp't \& Econ. Dev., 785 N.W.2d 796, 800 (Minn.App.2010)).
} 
Depending on the jurisdiction or law, a manager's flexibility in directing contractors differs greatly, which has an enormous impact on the creative process. Even though creativity is thought to be fleeting and unconfined, in practice, it typically involves bringing teams together at scheduled meetings. In these meetings there is a leader, someone acting much like a stage director, who shepherds an idea to its fruition. ${ }^{107}$

\section{Uber Case Sparks New Policy Debates About How We Classify Employees}

Uber is the $\$ 50$ billion mobile transportation company that poses as a technology company. ${ }^{108}$ Uber drivers $(160,000$ and growing $)^{109}$ transport customers in their personal cars, and use the company's application (installed on a provided iPhone) to make transactions. ${ }^{110}$ This past June, the Labor Commissioner of the California Department of Labor told Uber that it had misclassified one of its drivers as an independent contractor because a proper independent contractor, unlike an employee, is actually someone who operates an independent business, hired on for a specific project with a definite duration. ${ }^{111}$

The company argued it was simply operating an app that provides independent drivers access to its customer base. ${ }^{112}$ The California Labor Commission disagreed, finding, instead, that the drivers are an integral part of the well-orchestrated Uber operation. ${ }^{113}$ From requiring background checks to imposing restrictions on eligible vehicles and setting payments at a non-negotiable rate, Uber acted like an employer to its employee drivers. ${ }^{114}$

${ }^{107}$ E.g., CATMULL, supra note 60, at loc. 166-97.

${ }^{108}$ Mike Isaac \& Natasha Singer, California Says Uber Driver is Employee, Not a Contractor, N.Y. TIMES, Jun. 2015, http://www.nytimes.com/2015/06/18/business/uber-contests-california-labor-ruling-thatsays-drivers-should-be-employees.html?_r=0.

${ }^{109}$ Noam Scheiber, Growth in the 'Gig Economy' Fuels Work Force Anxieties, N.Y. TiMES, July 12, 2015, http://www.nytimes.com/2015/07/13/business/rising-economic-insecuritytied-to-decades-long-trend-in-employment-practices.html? $\mathrm{r}=0$.

${ }^{110}$ Berwick v. Uber, No. 11-46739, 2015 WL 4153765, at *3, 8 (CA. Dep't of Indus. Relations June 3, 2015).

111 See id. at *5.

${ }^{112} I d$. at $* 6$.

${ }^{113} \mathrm{Id}$.

${ }^{114} \mathrm{Id}$. 
As it happens ... Uber is not so much a labor-market innovation as the culmination of a generation-long trend. Even before the founding of the company in 2009, the United States economy was rapidly becoming an Uber economy writ large, with tens of millions of Americans involved in some form of freelancing, contracting, temping or outsourcing. ${ }^{115}$

Reading the facts of Berwick v. Uber, it is apparent that the company spent a great deal of money designing the position to favor a finding of independent contractor. ${ }^{116}$ Even the company's recruiting language illustrates its deliberate attempt to avoid employee classification: "Uber needs partners like you. Drive with Uber and earn great money as an independent contractor. Get paid weekly just for helping our community of riders get rides around town. Be your own boss and get paid in fares for driving on your own schedule." ${ }^{117}$ From the consumer's perspective, ordering an Uber is a bit of a roll of the dice. ${ }^{118}$ Without trainings or company cars and uniforms, the company settled for a lesser quality product in exchange for a higher profit margin. ${ }^{119}$ Like Uber's improper employee classification, such misclassification can create life-changing results for creatives.

${ }^{115}$ Noam Scheiber, Growth in the 'Gig Economy' Fuels Work Force Anxieties, N.Y. TIMES, July 12, 2015, http://www.nytimes.com/2015/07/13/business/rising-economicinsecurity-tied-to-decades-long-trend-in-employment-practices.html?_r $=0$.

${ }^{116}$ See Berwick v. Uber Techs., Inc., No. 11-46739 EK, 2015 WL 4153765, at *1-4 (Cal. Dep't of Indus. Rel. June 3, 2015).

${ }_{117}$ Sign up to Drive, Uber, https://get.uber.com/c1/?city_name=washingtonDC\&utm_source=Bing_Brand\&utm_campaign $=$ search $\% 7$ Cdesktop $\% 7$ Cdrivers $\% 7 \mathrm{Cwas}$ hington-DC\%7Ccountry-1\%7Ccity-

8\%7Ckeyword_uber\%20driver\%7Cmatchtype_e\%7Cad_9673883932\%7Ccampaign_bra nd\%7Cgroup_uberdriver\%3Eexact\&utm_medium=kenid_06ef919f-24e1-3808-6afa$000002 \mathrm{c} 2775 \mathrm{a}$ (last visited Oct. 13, 2015).

${ }^{118}$ See Mike Isaac, Uber Flunks the Better Business Bureau Test, BITs (Oct. 9, 2014, $3: 57$ PM), http://bits.blogs.nytimes.com/2014/10/09/uber-flunks-the-better-business-bureautest/? $\mathrm{r}=1$ (stating that Uber has received more than ninety customer complaints filed with the Bureau and with most of them centered on Uber's surge pricing, which is based on driver demand); see also Kessler, supra note 38 (quoting Caleb Merkl, the CEO of Maple, a New York delivery-only restaurant) ("'It's easy to add up the cost savings from having independent contractors-you know exactly how much you are saving per employee by not paying for workers' compensation - but it's much harder to quantify all of the benefits of having full-time employees that, in our view, offset many (if not all) of 1099 savings . . . . If you look at our delivery team, they are essentially our only point of human contact with our customers, so it's a case where who's doing the job and how they are doing it is incredibly important to our success."')

${ }^{119}$ See Isaac, supra note 118; Cf. Kessler, supra note 38 (citing interview with Caleb Merkl, the CEO of Maple, a New York delivery-only restaurant) (explaining how training 


\section{INTELleCtual PROPERTy CONCERNS}

Sure intellectual property rights are not relevant for an Uber driver-whose contributions are the labor of driving and a personal car-but employee classification makes or breaks a creative worker's rights to his or her intellectual property. Copyright law does not protect ideas, only expressions. ${ }^{120}$ This federal law protects qualifying "original works of authorship fixed in any tangible medium of expression." 121 Just about anything fixed on film, print, or the Internet is copyrightable. In fact, it is easier to give examples of what is not copyrightable than try to summarize the wide net of content that is. A list of names or facts is not copyrightable, ${ }^{122}$ nor is a fashion design, ${ }^{123}$ or a dramatic performance. ${ }^{124}$ But this essay is copyrightable, as is a magazine cover, ${ }^{125}$ and even a broadcast of your favorite football team. $^{126}$

\section{A. Contractors Own Copyrights}

Once content falls within the scope of protection, copyright holders may license or assign their work to others. ${ }^{127}$ But the current statutory scheme places limits on hiring parties who claim authorship. Authorship is presumed to be in the creator, but under the work made

is necessary to ensure deliveries and customer interactions abide by the company's values).

${ }^{120}$ Herbert Rosenthal Jewelry Corp. v. Kalpakian (Bee Pin Case), 446 F.2d 738, 742 (providing guidance on applying the idea/expression dichotomy) ("The critical distinction between "idea" and "expression" is difficult to draw. ... What is basically at stake is the extent of the copyright owner's monopoly-from how large an area of activity did Congress intend to allow the copyright owner to exclude others? We think the production of jeweled bee pins is a larger private preserve than Congress intended to be set aside in the public market without a patent.").

${ }^{121} 17$ U.S.C. $\S 102(a)(2012)$.

${ }^{122}$ Feist Publ'ns, Inc. v. Rural Tel. Serv. Co., 499 U.S. 340, 361 (1991).

${ }^{123}$ Melville B. Nimmer \& DAVID NimmeR, 1-2 Nimmer on COPYRIGHT $§ 2.08[\mathrm{H}][3]$ (2015).

${ }^{124}$ Garcia v. Google Inc., 766 F.3d 929, 941 (9th Cir. 2014), aff'd en banc, 786 F.3d 733,742 (9th Cir. 2015)

${ }^{125}$ Rosebud Entm't, LLC v. Prof. Laminating LLC, 958 F. Supp. 2d 600, 604-05 (D. Md. 2013).

${ }^{126}$ See generally Nat'l Football League v. PrimeTime 24 Joint Venture, 211 F.3d 10 (2d Cir. 2000).

${ }^{127} 17$ U.S.C. $\S 204$ (2012). 
for hire doctrine, it instead vests in the employer. ${ }^{128}$ This classification is anything but trivial; it dictates the term duration, and affects a creator's ability to terminate or to bring a Visual Artists Rights Act claim. ${ }^{129}$ "The contours of the work for hire doctrine therefore carry profound significance for freelance creators-including, artists, writers, photographers, designers, composers, and computer programmers - and for publishing, advertising, music, and other industries which commission their works." 130

Tucked in the definitions section of the Copyright Act is the "work made for hire" doctrine:

(1) a work prepared by an employee within the scope of his or her employment; or

(2) a work specially ordered or commissioned for use as a contribution to a collective work, as a part of a motion picture or other audiovisual work, as a translation, as a supplementary work, as a compilation, as an instructional text, as answer material for a test, or an atlas, if the parties expressly agree in a written instrument signed by them that the work shall be considered a work made for hire. ${ }^{131}$

Under $\S 101(2)$, Congress enumerated nine works that provide hiring parties authorship regardless of whether the creator was an employee or not. ${ }^{132}$ Still even for these works, a work made for hire agreement needs to be signed before the work begins. ${ }^{133}$ From a practical standpoint, $\S 101(2)$ is straightforward. If, for example, a screenwriter signs a work made for hire agreement before he starts writing, the film's producer is the rightful owner of the script.

${ }^{128} 17$ U.S.C. $§ 101(2012)$.

${ }^{129}$ Cmty. for Creative Non-Violence v. Reid, 490 U.S. 730 (1989). See Shannon M. Nolley, The Work for Hire Doctrine and the Second Circuit's Decision in Carter v. Helmsley for further background on the doctrine, and specifically how it relates to the Visual Artists Rights Act. 7 DePAul-LCA J. ART \& ENTM'T L. 103, 127 (1996) (“The Second Circuit's refusal [in Carter v. Helmsley] to consider the artists' retention of copyright in the work as a 'plus factor' brings to light the fundamental conflict in U.S. law between its long-held notion of copyright ownership, and the more recently recognized international concept of moral rights.").

${ }^{130}$ Reid, 490 U.S. at 737.

${ }^{131} 17$ U.S.C. $\S 101(2)(2012)$.

${ }^{132}$ Id. See also NIMMER, supra note 123, § 5.03(2)(a)(i).

${ }^{133} I d$. at $\S 5.03$. 
Conversely, when it comes to non $\S 101(2)$ works, agreements are basically irrelevant - an agreement cannot just label a contractor's work as "work made for hire" if it is not. The employer-employee relationship only manifests after a judge applies the agency law common law test from Community for Creative Non-Violence v. Reid ${ }^{134}$ to the specific working conditions involved. ${ }^{135}$

\section{Post-1978 Employer-Employee Test}

Under $\S 101(1)$, a court applies the general principles of agency law-now called the Reid or $C C N V$ test - to the circumstances leading up to the finished product. ${ }^{136}$ In Community for Creative NonViolence $v$. Reid, a sculpture artist was classified an independent contractor under the 1976 Copyright Act by the Supreme Court. ${ }^{137}$ The sculpture artist in Reid was approached by a nonprofit to construct a sculpture depicting homelessness. ${ }^{138}$ In exchange, he was paid a lump sum without benefits or taxes withheld. ${ }^{139} \mathrm{He}$ also worked in his own studio, and received little oversight from the nonprofit. ${ }^{140}$

In practice, the test can be thought of as an inquiry into whether the hiring party participated in the creative process, and whether the worker was treated like a conventional salaried employee. In contrast to other laws, copyright law actually places less weight on the exercise of control. ${ }^{141}$ Every case of this type certainly digs into the creative process - the process by which the idea was transformed into the final product - but not without first finding what resembles "the conventional relation[ship] of employer and employ[ee]."142

${ }^{134}$ Reid, 490 U.S. at $751-52$.

${ }^{135}$ NIMMER, supra note $123, \S 5.03$.

${ }_{137}^{136}$ Reid, 490 U.S. at $750-51$.

${ }^{137} \mathrm{Id}$. at 752 .

${ }^{138} I d$. at 733 .

${ }^{139} \mathrm{Id}$. at 753 .

${ }^{140} \mathrm{Id}$. at $752-53$.

${ }^{141}$ Aymes v. Bonelli, 980 F.2d 857, 861 (2d Cir. 1992) ("Some factors, therefore, will often have little or no significance in determining whether a party is an independent contractor or an employee. In contrast, there are some factors that will be significant in virtually every situation. These include: (1) the hiring party's right to control the manner and means of creation; (2) the skill required; (3) the provision of employee benefits; (4) the tax treatment of the hired party; and (5) whether the hiring party has the right to assign additional projects to the hired party. These factors will almost always be relevant and should be given more weight in the analysis, because they will usually be highly probative of the true nature of the employment relationship.").

${ }^{142}$ Reid, 490 U.S. at 740 . 
Central to the creative process is the delegation of artistic control. Similarly, "control is [usually] the principal guidepost" traditional employee classification because agency law defines a servant to mean one who is "subject to the other's control or right to control." ${ }^{, 144}$ However, in copyright law, even when the hiring party controls the work, if the other factors weigh heavily in favor of contractor status, this factor will actually be disregarded. ${ }^{145}$ In other words, because hiring parties are not supposed to collaborate with contractors, it will not be rewarded with copyright ownership when it disobeys this principal. Unless a worker is treated like a traditional salaried employee with-benefits, courts are cautious to classify a work as "made for hire." 146

In Marco v. Accent Publishing, the Third Circuit vacated a misapplication of the Reid test, and found a freelance photographer to be a contractor despite there being enough creative control by his employer. ${ }^{147}$ Marco was hired to shoot a series of images that were used in six consecutive issues of a costume jewelry trade journal. ${ }^{148}$ For the most part, the photos were shot in the photographer's home studio. ${ }^{149}$ The hiring party gave opinions on how the models and jewelry looked, but left the technical matters like color balance and light to the photographer. ${ }^{150}$ The hiring party also provided jewelry, models, and props to be photographed, and sketches to guide the photo's composition. ${ }^{151}$ At some points, an art director also attended some of the sessions to "[direct him] on the composition of a photograph ... the mood of the lighting, the emotion within a given scenario." 152 This was enough for the court to accept a finding of

\footnotetext{
${ }^{143}$ Clackamas Gastroenterology Assocs., P. C. v. Wells, 538 U.S. 440, 448 (2003).

${ }^{144}$ Id. (citing Restatement (Second) of Agency § 220(1) (1958)) (defining "employee" under the American Disability Act).

${ }^{145}$ See Reid, 490 U.S. at 751-52 (1989).

${ }^{146}$ Aymes v. Bonelli, 980 F.2d 857, 862-63 (2d Cir. 1992); see, e.g. Jessica Litman, Copyright, Compromise, and Legislative History, 72 CORNELL L. REV. 857, 890 (1987) ("[E]very case since Reid that has applied the test has found the hired party to be an independent contractor where the hiring party failed to extend benefits or pay social security taxes").

${ }^{147}$ Marco v. Accent Pub. Co., Inc., 969 F.2d 1547, 1553 (3rd Cir. 1992).

${ }^{148} I d$. at 1548 .

${ }^{149} \mathrm{Id}$. at 1549 .

${ }^{150} \mathrm{Id}$.

${ }^{151} \mathrm{Id}$. at $1548-49$

${ }^{152} \mathrm{Id}$. at 1552
} 
control. ${ }^{153}$ But it was not enough to find that Marco was an actual employee. $^{154}$

Even though the hiring party participated in the actual creative process, it did not act like an employer in other ways. For example, pay-roll taxes were not withheld, nor were benefits provided. ${ }^{155}$ The court was also persuaded by how limited the hiring party's engagement was: "The record does not suggest that [the hiring party] could assign any more than one issue's worth of photographs ... . during any particular period. [It] could not, for example, require [the photographer] to photograph its employee of the month." ${ }^{\text {"56 }} \mathrm{He}$ also did not hold regular hours with the company, even during the six-month period in question. ${ }^{157}$ Thus, this photographer was a contractor, and as a result, the copyrights to the photos were his. ${ }^{158}$

\section{Pre-1978 Employer-Employee Test}

Prior to the 1976 Copyright Act, it was much easier for a contractor's work to be "made for hire," as the courts applied the basic "Instance and Expense Test," instead of the Agency common law test. In 2013, the Second Circuit reinstated this test in Marvel v. Kirby, but only for pre-1978 works. ${ }^{159}$

The comic artist Jack Kirby is responsible for many of the characters that fill our screens and toy boxes. ${ }^{160}$ While working as a freelance artist in the sixties, he created-along with Stan Lee-entire teams of superheroes like the X-Men, the Fantastic Four, and the Avengers. ${ }^{161}$ Under the "Marvel Method," Stan Lee and a comic artist would talk ideas, then the artist would draw what they wished at

${ }^{153}$ Id. ("The only significant difference between this case and CCNV is that here the hiring party is in the business of regularly publishing photographs in connection with advertisements and articles. This distinction does not give rise to an employment relationship.").

${ }^{154}$ See id. at 1552 .

${ }^{155}$ Id. at 1549; see also SHL Imaging, Inc. v. Artisan House, Inc., 117 F. Supp. 2d 301 (S.D.N.Y. 2000) (finding contractor status when there was little control, taxes were not withheld, and benefits were not given).

${ }^{156} \mathrm{Id}$. at 1551 .

${ }^{157} \mathrm{Id}$.

${ }^{158} \mathrm{Id}$. at 1553 .

${ }^{159}$ Marvel Characters, Inc. v. Kirby, 726 F.3d 119, 137 (2d Cir. 2013).

${ }^{160} \mathrm{Id}$. at 124 .

${ }^{161} \mathrm{Id}$. at 125 . 
home. ${ }^{162} \mathrm{He}$ purchased all of the supplies necessary to draw the pages. ${ }^{163}$ If Lee approved the art then a writer would "put in all the dialogue and the captions." ${ }^{\text {164 }}$ Kirby was paid on a per-page rate, without any consideration for his future. ${ }^{165} \mathrm{He}$ did not hold a staffed position, nor did he receive vacation time, health benefits, a pension, or a cut in any of his character's success. ${ }^{166}$ To give an example of how valuable his work is today, the 2012 Avengers release alone brought in $\$ 1.5$ billion in worldwide box office proceeds ${ }^{167}$ Kirby himself made a mere $\$ 35,000$ for every year he worked as a freelancer for Marvel. ${ }^{168}$

When the heirs of his estate sought to terminate the original deal in 2010, the court found all his works to be "made for hire" property of the company. ${ }^{169}$ Because the works were created prior to the 1978 effective date of the 1976 Copyright Act, the court applied the now abolished "Instance and Expense" test. ${ }^{170}$ The instance prong merely requires that the hiring party provide the "impetus for" or participate in the work, or have "the power to supervise." ${ }^{171}$ The expense prong looks to see who bore the financial risk of the work. ${ }^{172}$ Even absent a showing of "instance," the test is still met if there is "a particularly strong showing that the work was made at its expense."173 Ultimately, the court sided with Marvel. ${ }^{174}$ To the court, while both parties bore some risk in the work, Marvel was the one on the hook for

${ }^{162} I d$. at 126.

${ }^{163} \mathrm{Id}$.

${ }^{164} I d$.

${ }^{165} \mathrm{Id}$.

${ }^{166}$ See id. at $125-126$.

${ }_{167}$ Marvel's The Avengers (2012), Box OfFICE MOJO, http://www.boxofficemojo.com/movies/?id=avengers11.htm (last updated Oct. 4, 2015, 7:11 PM).

${ }^{168}$ Jack Kirby, https://en.wikipedia.org/wiki/Jack_Kirby\#cite_ref-98 (last updated Sept. 28, 2015, 8:40 PM); see also Saul Braun, Shazam! Here Comes Captain Relevant, NY TIMES (May 2,1971), available at http://timesmachine.nytimes.com/timesmachine/1971/05/02/170499242.html?pageNumb er $=402$.

${ }^{169}$ Marvel, 726 F.3d at 124.

${ }^{170} \mathrm{Id}$. at 137.

${ }^{171} I d$. at 139 (citing Shapiro Berstein \& Co. v. Jerry Vogal Music Co., 221 F.2d 569, 570 (2d Cir. 1955)). The court notes that when a work already exists before the hiring party gets involved, the mere requesting of revisions is insufficient.

${ }_{172}$ Marvel, 726 F.3d at $140-43$. The Second Circuit struggled with the expense prong, feeling both parties bore risk, but sided with Marvel because it paid a flat rate to Kirby, and provided "creative and production value."

${ }^{173}$ Id. at 139 (citing Scherr v. Universal Match Corp., 417 F.2d 497, 501 (2d Cir. 1969)).

${ }^{174} \mathrm{Id}$. at 143. 
how successful a work would become. ${ }^{175}$ Furthermore, Kirby was technically paid for accepted pages. ${ }^{176}$ However, Kirby was not paid for the countless pages that were rejected. ${ }^{177}$

There is little doubt that if the court had applied the modern "employer-employee" test, the Kirby estate would have won because the court would have recognized Kirby as a true contractor. ${ }^{178}$ Even the Second Circuit admits this fact: "it is undisputed that Kirby was a freelancer." 179 As well articulated by the American Society of Architectural Illustrators, Kirby would have had a different outcome after 1978:

When reaching its decision, the Second Circuit ignored the conventional employer/employee relationship defined under the common law of agency, ignored Kirby's authorial rights under the 1909 Act and the 1976 Act, ignored the teachings of the Supreme Court precedent of [Reid] whereby the Court defined the seminal conditions necessary for work-for-hire regarding freelance authors, and nullified Congress's clear objectives in enacting copyright termination provisions for authors. Instead, the court relied on an erroneous, simplistic and controversial judicial test. Called the "instance and expense" test, it redefines nearly any business

${ }^{175} \mathrm{Id}$. at 140 .

${ }^{176}$ Marvel, 726 F.3d at 142.

${ }^{177}$ Id. at 125-26; Making Music: IP \& the Creative Process, GEO. MASON UNIV.: Center FOR THE PROtection OF Intell. Prop. (Sept. 30-Oct. 1, 2015), http://cpip.gmu.edu/conferences/. (Marc Beeson, a panelist at the CPIP George Mason 2015 conference in the session Making Music: IP \& the Creative Process, remarks that fans do not realize that for every hit song produced, a songwriter spends thousands of hours spent on unknown songs that were never selected. Not to mention the other thousands of hours spent on mastering the skills necessary to be a professional songwriter).

178 See Joseph Cornelius Johnson, My Hero?: The Work for Hire Doctrine and Termination Rights in Marvel Characters, Inc. v. Kirby, 14-18, available at http://scholarship.shu.edu/cgi/viewcontent.cgi?article=1498\&context=student_scholarshi p; see, e.g., Wayne M. Cox, The Fantastic Failure: How Current Copyright Law Stacks the Deck Against the Original Authors of Justice, 55 IDEA 361, 379 (2015).

${ }^{179}$ Marvel, 726 F.3d at 125 . 
transaction between an independent creator and a commissioning party as work-for-hire. ${ }^{180}$

\section{B. $\quad$ Contractors Can Terminate}

The work made for hire doctrine puzzles many, even experts of copyright law. Employment contracts regularly include "work made for hire" language, so the phrase is thrown around to describe what is actually an assignment, a license, or nothing at all. As a result, wise practitioners cover their bases by including both work made for hire and assignment language in their contracts. ${ }^{181}$ An assignment is the legal transfer of all exclusive rights (in writing) of a copyright. ${ }^{182}$ With this transfer, companies can freely use the copyright just like an owner, but with significant artist rights limitations. ${ }^{183}$ In the case of fine art, a company is limited in how it labels, manipulates, or handles a physical piece of art. ${ }^{184}$ And, most importantly, all assigned copyrights are subject to the filing of a termination notice. ${ }^{185} \mathrm{~A}$ work made for hire is a work in which the legal author is not the creator but is a hiring party. ${ }^{186}$ Because the creator never authored the work to begin with, he or she cannot claim any of the author rights provided by law.

${ }^{180}$ Cynthia Turner \& Dena Matthews, Understanding the Kirby Case: ASAI joins Amicus Brief for Kirby v. Marvel Comics, Disney, American Society of Architectural Illustrators, (June 26 , 2014),

https://americansocietyofarchitecturalillustrators.wordpress.com/2014/06/26/understandin g-the-kirby-case-asai-joins-amicus-brief-for-kirby-v-marvel-comics-disney/. Prior to the Kirby settlement, Bruce Lehman, former Director of the U.S. Patent and Trademark Office, and Ralph Oman, former U.S. Register of Copyrights, wrote an amicus brief to the Supreme Court on behalf of freelancers. The Turner article provides an excellent summary and outline of their legal argument. Id.

${ }^{181}$ Email interview with Joel Leviton, Partner, Stinson, Leonard, Street (Jan. 8, 2016) ("Contracts often refer to the works that are to be created as 'work for hire.' However, not all copyrightable works qualify to be a work for hire. If a work does not qualify as a work made for hire, to transfer ownership the copyrights must be assigned. There are benefits, for the owning party, for a work to be considered a work made for hire. For example, no termination rights. As such,, in the first instance, the party who will own the copyright likely will want the work to be considered a work made for hire if possible. But, in the event a work does not qualify as a work made for hire, the party seeking to own the work will want to assure it obtains an assignment in the alternative.").

18217 U.S.C. $\$ 1320(2012)$

${ }^{183}$ NIMMER, supra note 123 , at $\S 5.03$.

${ }^{184}$ Visual Artists Rights Act, 17 U.S.C. § 106(A) (2012).

18517 U.S.C. $\$ 1305$ (2012).

${ }^{186}$ NIMMER, supra note 123 , at $\S 5.03$. 
While not always packaged as an inalienable ${ }^{187}$ author right, the termination right dates back to the Statute of Anne. ${ }^{188}$ Today copyrights enjoy lengthy terms, but authors once had to renew registrations to extend their term duration. ${ }^{189}$ As a result of this system, assignments entered into during the first term ended with the beginning of a renewal term. When it came time to craft the 1976 Copyright Act, Congress chose to abandon the unpopular renewal requirement, and replaced it with a codified termination right. ${ }^{190}$ Congress recognized that freelancers were too often taken advantage of in the marketplace, particularly when just starting out. An inalienable termination right would grant authors of successful work a second chance at profits. ${ }^{191}$

Works under the 1976 Copyright Act are governed by the statutory scheme laid out in section 203. ${ }^{192}$ Between twenty-five and thirty-three years after an assignment, a creator may file a termination notice with the U.S. Copyright Office. The right will then terminate (aka return to the original creator) within a five-year window thereafter. As a result of the work made for hire exception and the inalienability of the right, much litigation has spurred, and will continue to come,

${ }^{187}$ Fred Fisher Music Co. v. M. Witmark \& Sons, 318 U.S. 643, 656 (1943), superseded by statute, Copyright Act of 1976, Pub. L. No. 94-553, 90 Stat. 2541.

${ }^{188}$ Statute of Anne, 1710, 8 Anne, c. 19 , reprinted in COPYRight LaW Volume I: THE SCOPE AND Historical ConteXt 189 (Benedict A. C. Atkinson \& Brian F. Fitzgerald eds. 2011).

${ }^{189}$ Copyright Act of 1909, ch. 320, 35 Stat. 1075 (1909) (duration, renewal and extension). ("[T]he proprietor of such copyright shall be entitled to a renewal and extension of the copyright in such work for the further term of twenty-eight years ...").

${ }^{190}$ H.R. REP. No. 94-1476, at 134 (1976), reprinted in 17 U.S.C. $\$ 304$ at 1152 (2012) ("One of the worst features of the present copyright law is the present copyright law is the provision for renewal of copyright. A substantial burden an expense, this unclear and highly technical ... is the cause of inadvertent and unjust loss of copyright.").

${ }^{191}$ See Stewart v. Abend, 495 U.S. 207, 230 (1990) (the reversion right was intended to be inalienable); Peter S. Menell, Pooh-Poohing Copyright Law's Inalienable Termination Rights 57 J. COPYRIGHT SOC'Y 799, 806 (citing DISCUSSION \& COMMENTS ON THE REPORT OF THE REGISTER OF COPYRIGHTS ON THE GENERAL REVISION OF THE U.S. COPYRIGHT LAW 93 (Gov't Printing Off. 1963) (rejected language included "limiting all copyright assignments to twenty years with automatic reversions thereafter; permitting termination of assignments deemed to be unfair to authors; and granting termination of assignment rights to who authors who were paid only a lump sum upfront.").

${ }^{192} 17$ U.S.C. $§ 203$ (2012). ("In the case of any work other than a work made for hire, the exclusive or nonexclusive grant of a transfer or license of copyright or of any right under a copyright, executed by the author on or after January 1, 1978, otherwise than by will, is subject to termination ..."). 
between hiring parties and freelancers in regards to employee-status, and other technical matters. ${ }^{193}$

The easiest way to avoid this risk is to hire employees instead of freelancers, and to provide workers with employee benefits.

\section{CONCLUSION}

Perhaps no creative industry has felt the affects of this changing workforce more than the newspaper industry. Once a copyright industry giant, ${ }^{194}$ newspapers now struggle to stay profitable in the digital marketplace. ${ }^{195}$ And "labor is still the biggest cost," said Paul Godfrey, President of Postmedia Network. ${ }^{196}$ In 2000, there were 25,593 staff reporters and writers hired by newspapers; in 2013, just 17,422 and declining. ${ }^{197}$ That's a $32 \%$ drop, which is still less than the $43 \%$ drop felt by staff photographers. ${ }^{198}$

${ }^{193}$ See, e.g. Milne v. Stephen Slesinger, Inc., 430 F.3d 1036, 1040 (9th Cir. 2005) (Winnie the Pooh); Penguin Group, Inc. v. Steinbeck, 573 F.3d 193 (2d Cir. 2008); Larson v. Warner Bros Entm't (Superman), 213 U.S. Dist. LEXIS 55949 (C.D. Cal. 2013). For commentary on the YMCA case, see Eriq Gardner, Village People's Victor Wills Wins Huge Rights Reversion Case Over 'YMCA', BILLBOARD, May 8, 2012, http://www.billboard.com/biz/articles/news/1097011/village-peoples-victor-willis-winshuge-rights-reversion-case-over-ymca.

${ }^{194}$ Size of the Copyright Industries, COPYRIGHT LAW REVISION, STUdies PREPARED FOR THE SubCOMmitTEe On PATENTS, TRAdEMARKS, AND COPYRIGHTS, 28 tbl. II (1960), http://copyright.gov/history/studies/study2.pdf (Newspaper publishing's national income was over $\$ 1.5$ billion, while the movie industry brought in only $\$ 917$ million).

${ }^{195}$ Monica Anderson, At newspaper, photographers feel the brunt of job cuts, Nov. 11, 2013, http://www.pewresearch.org/fact-tank/2013/11/11/at-newspapers-photographersfeel-the-brunt-of-job-cuts/ ("Shrinking newsroom budgets play a significant part, but so does the explosion of mobile technology and social media, making it easier for citizens and non-professionals to capture and share images. When it laid off several photographers in 2011, CNN cited the 'impact of user-generated content and social media ... in breaking news,' as a key reason.").

${ }^{196}$ Sarah A. Howes, Newspaper is Made from Megabtyes, Copyright Alliance, Oct. 13 ,

https://copyrightalliance.org/2015/10/newspaper_made_megabytes\#.VoRYMotSb8E (coverage of the Center for the Protection of Intellectual Property event Future of the News).

${ }^{197}$ Anderson, supra note 195. However, there appears to be an increase in the number of newsroom jobs at either very big or very small newspapers. Ken Doctor, Newsonomics: The halving of America's daily newsroom, NIEMAN LAB, July 28, 2015, http://www.niemanlab.org/2015/07/newsonomics-the-halving-of-americas-dailynewsrooms/.

${ }^{198}$ Anderson, supra note 195. 
An email exchange between journalist Nate Thayer and the Global Editor of the Atlantic, Thayer details how the magazine- now only offering $\$ 100$ to re-post his articles-once offered him $\$ 125,000$ to write six articles a year as a staff journalist. ${ }^{199}$ This new era may require new ways of delivering the news, but quality still demands well-compensated journalists who have the funding to investigate matters of public importance, and the capacity to master their craft. ${ }^{200}$

Creativity is best served when collaborators are fairly compensated, and when managers have total discretion to give as much freedom as they see fit. More and more employers are choosing the contractor model, which only adds to the frustrations felt by our workforce and sacrifices the quality of the creative products entering our marketplace.

Companies of all sizes should perform internal audits of contractor relationships to evaluate whether roles should be clarified or re-classified. ${ }^{201}$ This audit should take into consideration the company's creative process and the worker's role in producing copyrightable content. Additionally, workers should look to organizing groups for advocacy support, such as a union, trade association, or to Sara Horowitz's Freelancers Union. Finally, organizations dedicated to bettering the lives of American artists ought to survey employee classification in their communities to provide policymakers a clearer picture of revenue streams and misclassification in the arts.

It may be that new lines may need to be drawn on employee classification - that this legal framework has not been poked enoughbut in the meantime, the decision to hire contractors involves much more than pinching pennies. Especially when you have a Picasso on staff.

199 Nate Thayer, A Day in the Life of a Freelance Journalist (2013), https://natethayer.wordpress.com/2013/03/04/a-day-in-the-life-of-a-freelance-journalist2013/.

${ }^{200}$ The general consensus of the panelists - made up of news industry representativeswas that cutting labor costs was a poor long-term solution, as it would sacrifice quality. Howes, supra note 196.

${ }^{201}$ Peter C. Godfrey, The Employee or Independent Contractor Dilemma: Practical Advice to Minimize Misclassification-Related Risks and Exposure, ASPATORE 6-9 (2014). 


\section{APPENDIX}

\section{Federal And Minnesota State \\ EMPLOYEE CLASSIFICATION \\ EMPLOYEE V. INDEPENDENT CONTRACTOR}

This chart is only meant to serve as a guide to the various laws affected by employee classification. Every situation is evaluated on a case-bycase basis. Laws are subject to change, and up to interpretation by the judiciary. Chart updated by Sarah A. Howes, J.D. in October 2015.

\begin{tabular}{|c|c|c|c|}
\hline Law & Description & $\begin{array}{l}\text { Relevant Statutes } \\
\text { and Case Law }\end{array}$ & Test \\
\hline $\begin{array}{l}\text { DEED: } \\
\text { Unemploy } \\
\text { ment } \\
\text { Insurance }\end{array}$ & $\begin{array}{l}\text { "The Minnesota } \\
\text { Unemployment } \\
\text { Insurance (UI) } \\
\text { Program provides } \\
\text { a temporary } \\
\text { partial wage } \\
\text { replacement to } \\
\text { those Minnesota } \\
\text { workers who } \\
\text { become } \\
\text { unemployed } \\
\text { through no fault } \\
\text { of their own." } \\
\text { Employers are } \\
\text { only required to } \\
\text { pay UI taxes for } \\
\text { employees. }\end{array}$ & $\begin{array}{l}\text { Statute: Minn. Stat. } \\
\text { \$ 268. } \\
\text { Cases: Guhlke v. } \\
\text { Roberts Truck } \\
\text { Lines, } 128 \text { N.W.2d } \\
324 \text { (1964) ("the } \\
\text { most important } \\
\text { factor considered in } \\
\text { light of the nature } \\
\text { of the work is the } \\
\text { right of the } \\
\text { employer to control } \\
\text { the means and } \\
\text { manner of the } \\
\text { performance"); St. } \\
\text { Croxi Sensory, } \\
\text { Inc., v. DEED, } 785 \\
\text { N.W.2d } 796 \text { (Minn. } \\
\text { Ct. App. 2010). }\end{array}$ & $\begin{array}{l}\text { (1) The right to } \\
\text { control the means } \\
\text { and manner of } \\
\text { performance; (2) } \\
\text { the mode of } \\
\text { payment; (3) the } \\
\text { furnishing of } \\
\text { material or tools; } \\
\text { (4) the control of } \\
\text { the premises where } \\
\text { the work is done; } \\
\text { and (5) the right of } \\
\text { the employer to } \\
\text { discharge. }\end{array}$ \\
\hline
\end{tabular}




\begin{tabular}{|c|c|c|c|}
\hline $\begin{array}{l}\text { DLS: } \\
\text { Minnesota } \\
\text { Fair Labor } \\
\text { Standards } \\
\text { Act }\end{array}$ & $\begin{array}{l}\text { Employees, } \\
\text { whether part-time } \\
\text { or full-time, must } \\
\text { receive a } \\
\text { minimum wage } \\
\text { and overtime pay } \\
\text { that is set by law. } \\
\text { www.dli.mn.gov/ } \\
\text { LS/Pdf/minwage_- } \\
\text { er-rates.pdf }\end{array}$ & $\begin{array}{l}\text { Statue: The law } \\
\text { exempts certain } \\
\text { workers. See Minn. } \\
\text { Stat. § 177.23, } \\
\text { subd. } 7 .\end{array}$ & $\begin{array}{l}\text { Adopts the same } \\
\text { test as DEED }\end{array}$ \\
\hline $\begin{array}{l}\text { DLS: } \\
\text { Workers' } \\
\text { Compensati } \\
\text { on }\end{array}$ & $\begin{array}{l}\text { Employees } \\
\text { receive benefits } \\
\text { for injuries or } \\
\text { illnesses caused or } \\
\text { made worse by } \\
\text { the workplace, } \\
\text { regardless of fault } \\
\text { by either the } \\
\text { employer or } \\
\text { employee. }\end{array}$ & $\begin{array}{l}\text { Statute: Minn. Stat. } \\
\S 176.011 \text {, subd. } 9 . \\
\text { Case: Iverson v. } \\
\text { Independent } \\
\text { School District, } \\
257 \text { N.W.2d 573 } \\
\text { (1977) (finding an } \\
\text { independent } \\
\text { contractor) }\end{array}$ & $\begin{array}{l}\text { Adopts the same } \\
\text { test as DEED }\end{array}$ \\
\hline
\end{tabular}




\begin{tabular}{|c|c|c|c|}
\hline $\begin{array}{l}\text { MDOR: } \\
\text { State } \\
\text { Income Tax }\end{array}$ & $\begin{array}{l}\text { Employers must } \\
\text { "withhold and } \\
\text { deposit income } \\
\text { taxes, Social } \\
\text { Security taxes and } \\
\text { Medicare taxes." } \\
\text { Contractors are } \\
\text { permitted to file } \\
\text { Schedule C forms } \\
\text { to deduct business } \\
\text { expenses. }\end{array}$ & \begin{tabular}{|l|} 
Statute: Minn. Stat. \\
\$ 290.92, subd. \\
$1(3)$. \\
Agency Doc: \\
Withholding Fact \\
Sheet 8 ("If you are \\
generally in control \\
of (or have the \\
right to control) \\
these factors, the \\
worker is most \\
likely your \\
employee.") \\
Case: Hetland v. \\
Comm'n of \\
Revenue, 2011 WL \\
1045457 (Minn. \\
Tax Regular Div. \\
2011) (finding \\
employees)
\end{tabular} & $\begin{array}{l}\text { (1) Behavior } \\
\text { Control; (2) } \\
\text { Financial Control; } \\
\text { and (3) } \\
\text { Relationship of the } \\
\text { Parties }\end{array}$ \\
\hline $\begin{array}{l}\text { EEOC: } \\
\text { Title VII }\end{array}$ & $\begin{array}{l}\text { Title VII of the } \\
\text { Civil Rights Act } \\
\text { of } 1964 \text { protects } \\
\text { against many } \\
\text { offenses, } \\
\text { including sexual } \\
\text { harassment. It } \\
\text { applies to both } \\
\text { government } \\
\text { agencies and } \\
\text { private businesses } \\
\text { who employ more } \\
\text { than } 15 \\
\text { employees. The } \\
\text { law prohibits }\end{array}$ & $\begin{array}{l}\text { Statute: } 42 \text { U.S.C. } \\
\text { § 2000e(f) (Title } \\
\text { VII) } \\
\text { Cases: Farlow v. } \\
\text { Wachovia Bk. of } \\
\text { North Carolina, } \\
\text { 259 F.3d 309, } 313 \\
\text { (4th Cir. 2001) } \\
\text { (finding a } \\
\text { contractor) ("We } \\
\text { place greater } \\
\text { weight on: 1) the } \\
\text { financial } \\
\text { relationship }\end{array}$ & $\begin{array}{l}\text { Restatement } \\
\text { (Second) of } \\
\text { Agency } \S 220 \\
(1958) \text {. } \\
\text { (1) The hiring } \\
\text { party's right to } \\
\text { control the manner } \\
\text { and means by } \\
\text { which the product } \\
\text { is accomplished; } \\
\text { (2) the skill } \\
\text { required; (3) the } \\
\text { source of the } \\
\text { instrumentalities } \\
\text { and tools; }(4) \text { the }\end{array}$ \\
\hline
\end{tabular}




\begin{tabular}{|c|c|c|}
\hline $\begin{array}{l}\text { ad } \\
\text { int } \\
\text { we } \\
\text { pe }\end{array}$ & $\begin{array}{l}\text { between the parties } \\
\text { in which she was } \\
\text { paid not a salary } \\
\text { but only in } \\
\text { response to her } \\
\text { bills, for services } \\
\text { actually rendered; } \\
\text { 2) the financial } \\
\text { relationship } \\
\text { between the parties } \\
\text { in which Wachovia } \\
\text { did not withhold or } \\
\text { pay any taxes that } \\
\text { are incident to an } \\
\text { employment } \\
\text { relationship; } 3 \text { ) the } \\
\text { financial } \\
\text { relationship } \\
\text { between the parties } \\
\text { in which Farlow } \\
\text { did not receive } \\
\text { employee benefits } \\
\text { such as medical } \\
\text { and life insurance; } \\
\text { 4) Farlow's filing } \\
\text { of income tax } \\
\text { returns under a } \\
\text { self-employed } \\
\text { status; 5) the } \\
\text { express intent of } \\
\text { the parties as } \\
\text { indicated in the } \\
\text { contract Farlow } \\
\text { signed labeling her } \\
\text { as an independent } \\
\text { contractor; } 6 \text { ) that } \\
\text { Farlow did not } \\
\text { work exclusively } \\
\text { for Wachovia } \\
\text { during her working }\end{array}$ & $\begin{array}{l}\text { location of the } \\
\text { work; (5) the } \\
\text { duration of the } \\
\text { relationship } \\
\text { between the } \\
\text { parties; (6) whether } \\
\text { the hiring party has } \\
\text { the right to assign } \\
\text { additional projects } \\
\text { to the hired party; } \\
\text { (7) the extent of } \\
\text { the hired party's } \\
\text { discretion over } \\
\text { when and how long } \\
\text { to work; (8) the } \\
\text { method of } \\
\text { payment; (9) the } \\
\text { hired party's role in } \\
\text { hiring and paying } \\
\text { assistants; (10) } \\
\text { whether the work } \\
\text { is part of the } \\
\text { regular business of } \\
\text { the hiring party; } \\
\text { (11) whether the } \\
\text { hiring party is in } \\
\text { business; (12) the } \\
\text { provision of } \\
\text { employee benefits; } \\
\text { and (13)the tax } \\
\text { treatment of the } \\
\text { hired party. Note: } \\
\text { No one factor will } \\
\text { prevail alone. }\end{array}$ \\
\hline
\end{tabular}




\begin{tabular}{|c|c|c|c|}
\hline & & $\begin{array}{l}\text { relationship with it; } \\
\text { and (7) that } \\
\text { Wachovia } \\
\text { exercised no } \\
\text { control over the } \\
\text { manner of her } \\
\text { work.") }\end{array}$ & \\
\hline $\begin{array}{l}\text { DOL: } \\
\text { FLSA - } \\
\text { Federal } \\
\text { Minimum } \\
\text { Wage Law }\end{array}$ & $\begin{array}{l}\text { This law applies } \\
\text { to government } \\
\text { agencies, schools, } \\
\text { and companies } \\
\text { that engage in } \\
\text { interstate } \\
\text { commerce } \\
\text { (typically } \\
\$ 500,000 \text { in } \\
\text { annual volume). } \\
\text { Non-exempt } \\
\text { employees must } \\
\text { be provided a } \\
\text { minimum wage } \\
\text { (currently } \$ 7.25 \text { ) } \\
\text { and be provided } \\
\text { overtime pay. }\end{array}$ & $\begin{array}{l}\text { Statute: Fair Labor } \\
\text { Standards Act, 29 } \\
\text { U.S.C. } \$ 203(\mathrm{e})(1) \\
\text { Cases: See, e.g., } \\
\text { Hopkins v. } \\
\text { Cornerstone Am., } \\
545 \text { F.3d 338, 343 } \\
\text { (5th Cir. 2008) } \\
\text { ('To determine if a } \\
\text { worker qualifies as } \\
\text { an employee, we } \\
\text { focus on whether, } \\
\text { as a matter of } \\
\text { economic reality, } \\
\text { the worker is } \\
\text { economically } \\
\text { dependent upon the } \\
\text { alleged employer } \\
\text { or is instead in } \\
\text { business for } \\
\text { himself.") } \\
\text { See DOL, } \\
\text { Administrator's } \\
\text { Interpretation No. } \\
\text { 2015-1 (2015). }\end{array}$ & $\begin{array}{l}\text { Economic Realities } \\
\text { Factors typically } \\
\text { include: A) The } \\
\text { extent to which the } \\
\text { work performed is } \\
\text { an integral part of } \\
\text { the employer's } \\
\text { business; B) the } \\
\text { worker's } \\
\text { opportunity for } \\
\text { sharing or loss } \\
\text { depending on his } \\
\text { or her managerial } \\
\text { skills; (C) the } \\
\text { extent of the } \\
\text { relative } \\
\text { investments of the } \\
\text { employer and the } \\
\text { worker; (D) } \\
\text { whether the work } \\
\text { performed requires } \\
\text { special skills and } \\
\text { initiative; (E) the } \\
\text { permanency of the } \\
\text { relationship; and } \\
\text { (F) the degree of } \\
\text { control exercised } \\
\text { or retained by the } \\
\text { employer. } \\
\text { Note: Some courts } \\
\text { have considered } \\
\text { other factors. }\end{array}$ \\
\hline
\end{tabular}




\begin{tabular}{|c|c|c|c|}
\hline \begin{tabular}{|l} 
DOL: \\
Federal \\
Family and \\
Medical \\
Leave Act
\end{tabular} & $\begin{array}{l}\text { This law entitles a } \\
\text { worker to unpaid, } \\
\text { job-protected } \\
\text { leave for certain } \\
\text { family and } \\
\text { medical reasons. } \\
\text { A worker's health } \\
\text { insurance may not } \\
\text { be canceled } \\
\text { during the leave. } \\
\text { Applies to } \\
\text { employees whose } \\
\text { employer employs } \\
\text { fifty or more } \\
\text { employees within } \\
75 \text { miles of the } \\
\text { worksite. }\end{array}$ & $\begin{array}{l}\text { Statute: } 29 \text { U.S.C. } \\
\$ 2611(3) \\
\text { Cases: Bonnetts v. } \\
\text { Arctic Express, } \\
\text { Inc., } 7 \text { F. Supp. 2d } \\
\text { 977 (S.D. Ohio } \\
\text { 1998). }\end{array}$ & $\begin{array}{l}\text { Adopts the same } \\
\text { test as FLSA }\end{array}$ \\
\hline $\begin{array}{l}\text { IRS: } \\
\text { Federal } \\
\text { Income Tax }\end{array}$ & $\begin{array}{l}\text { Both the federal } \\
\text { government and } \\
\text { your state } \\
\text { government is } \\
\text { allowed to tax } \\
\text { income. }\end{array}$ & $\begin{array}{l}\text { Agency Doc: Topic } \\
762 \text { - Independent } \\
\text { Contractor v. } \\
\text { Employee } \\
\text { Cases: Robert } \\
\text { Patrick Day v. } \\
\text { Comm', } 80 \text { T.C.M. } \\
834 \text { (2000); Gierek } \\
\text { v. Commissioner, } \\
\text { 66 T.C.M. 1866 } \\
\text { (1993) (finding } \\
\text { employee) } \\
\text { (“doubtful } \\
\text { questions should be } \\
\text { resolved in favor of } \\
\text { employment in } \\
\text { order to accomplish } \\
\text { the remedial } \\
\text { purposes of the } \\
\text { legislation } \\
\text { involved). }\end{array}$ & $\begin{array}{l}\text { (1) Behavior } \\
\text { Control; (2) } \\
\text { Financial Control; } \\
\text { and (3) } \\
\text { Relationship of the } \\
\text { Parties }\end{array}$ \\
\hline
\end{tabular}




\begin{tabular}{|c|c|c|c|}
\hline $\begin{array}{l}\text { NLRA: } \\
\text { Federal } \\
\text { Labor Laws }\end{array}$ & $\begin{array}{l}\text { The NLRB is the } \\
\text { government } \\
\text { authority that } \\
\text { regulates } \\
\text { collective } \\
\text { bargaining and the } \\
\text { formation of labor } \\
\text { unions. } \\
\text { All workers are } \\
\text { afforded certain } \\
\text { collective } \\
\text { bargaining rights, } \\
\text { including section } \\
7 \text { rights to engage } \\
\text { in concerted } \\
\text { activity, but only } \\
\text { employees are } \\
\text { afforded the full } \\
\text { protections of this } \\
\text { law. }\end{array}$ & \begin{tabular}{|l} 
Statute: 29 U.S.C. \\
$\S 152(3)$ \\
Cases: FedEx \\
Home Delivery v. \\
NLRB, 563 F.3d \\
492,496 (D.C. Cir. \\
2009) \\
See generally \\
Micah Prieb \\
Stolzfus Jost, Note, \\
Independent \\
Contractors, \\
Employees, and \\
Entrepreneurialism \\
Under the National \\
Relations Act: A \\
Worker-by-Worker \\
Approach 68 \\
Wash. \& Lee L. \\
Rev 311 (2011) \\
(providing a history \\
and illustrating \\
various attempts to \\
address \\
misclassification, \\
including Pres. \\
Obama's 2011 \\
proposed budget to \\
increase the DOL \\
staff to identify \\
employers who \\
misclassify \\
employees).
\end{tabular} & $\begin{array}{l}\text { Restatement } \\
\text { (Second) of } \\
\text { Agency } \S 220 \\
(1958) .\end{array}$ \\
\hline $\begin{array}{l}\text { Federal: } \\
\text { U.S. } \\
\text { Copyright } \\
\text { Act }\end{array}$ & $\begin{array}{l}\text { Under the work } \\
\text { made for hire } \\
\text { doctrine, the } \\
\text { copyrighted } \\
\text { products of an }\end{array}$ & \begin{tabular}{|l|} 
Statute: 17 U.S.C. \\
$\$ 101(1),(2)$ \\
Cases: Community \\
for Creative Non-
\end{tabular} & $\begin{array}{l}\text { All Agency Law } \\
\text { Factors (above) for } \\
\text { post-1978 works, } \\
\text { but these are } \\
\text { considered in most }\end{array}$ \\
\hline
\end{tabular}




\begin{tabular}{|c|c|c|}
\hline $\begin{array}{l}\text { employee are } \\
\text { owned by his or } \\
\text { her employer. } \\
\text { Note: certain non- } \\
\text { employees (aka } \\
\text { statutory } \\
\text { employees) may } \\
\text { also be subject to } \\
\text { this doctrine if } \\
\text { their work is one } \\
\text { of the enumerated } \\
\text { works and an } \\
\text { agreement is } \\
\text { signed. }\end{array}$ & $\begin{array}{l}\text { Violence v. Reid v. } \\
\text { Reid, } 490 \text { U.S. } 730 \\
\text { (1989) (post-1978 } \\
\text { works) (Agency } \\
\text { Law Test); Marvel } \\
\text { v. Kirby 726 F.3d } \\
119 \text { (2d Cir. 2013) } \\
\text { (pre-1978 works) } \\
\text { (“Instance and } \\
\text { Expense Test”). }\end{array}$ & $\begin{array}{l}\text { circumstances: } \\
\text { (1) the hiring } \\
\text { party's right to } \\
\text { control the manner } \\
\text { and means of } \\
\text { creation; (2) the } \\
\text { skill required; (3) } \\
\text { the provision of } \\
\text { employee benefits; } \\
\text { (4) the tax } \\
\text { treatment of the } \\
\text { hired party; and } \\
\text { (5) whether the } \\
\text { hiring party has the } \\
\text { right to assign } \\
\text { additional projects } \\
\text { to the hired party. } \\
\text { Aymes v. Bonelli, } \\
980 \text { F.2d } 857 \text { (2d } \\
\text { Cir. 1992) (noting } \\
\text { that at the time } \\
\text { "every case since } \\
\text { Reid that has } \\
\text { applied the test has } \\
\text { found the hired } \\
\text { party to be an } \\
\text { independent } \\
\text { contractor where } \\
\text { the hiring party } \\
\text { failed to extend } \\
\text { benefits or pay } \\
\text { social security } \\
\text { taxes.) }\end{array}$ \\
\hline
\end{tabular}


Early Works by Pablo Picasso

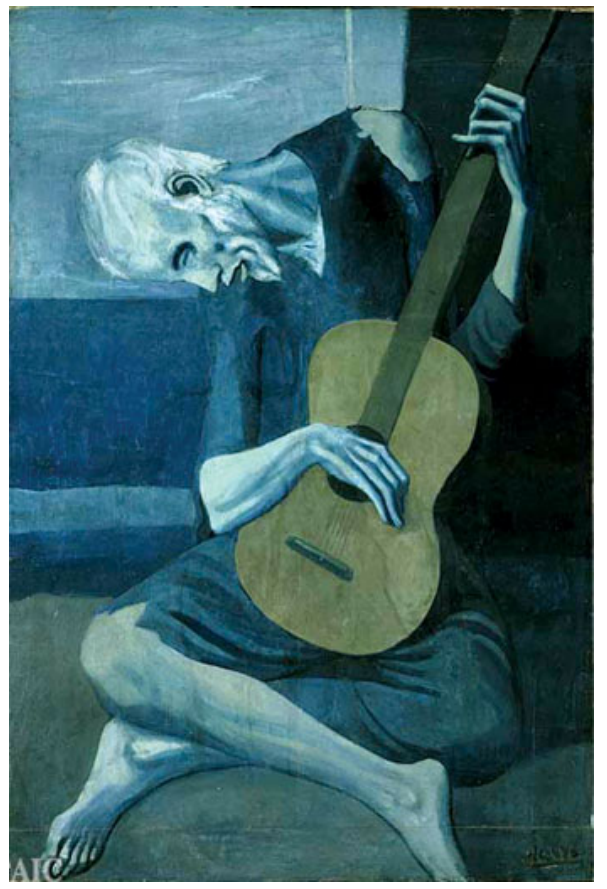

The Old Guitarist (1903)

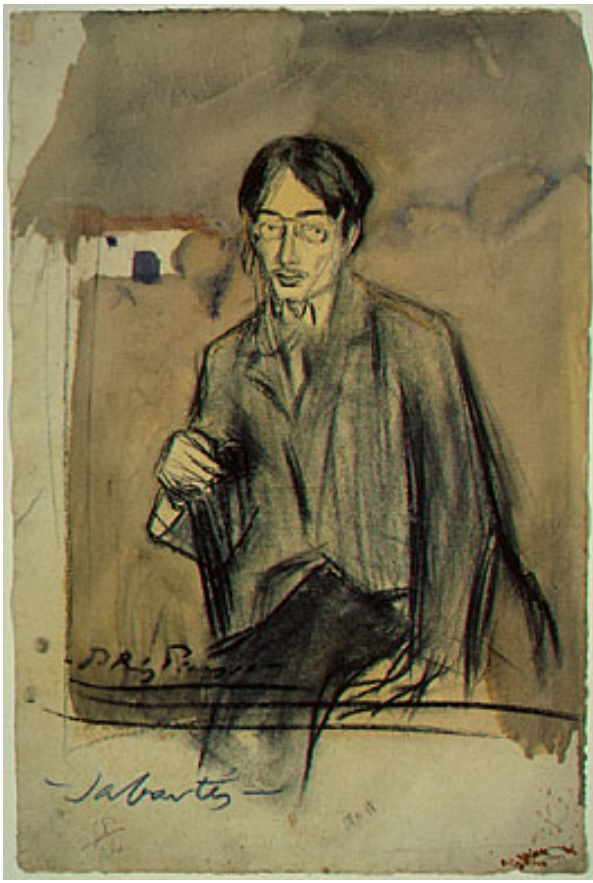

Sabartès Seated (1900) 